\title{
Enhanced Plant Rooting and Crop System Management for Improved N Use Efficiency
}

\author{
Ciro A. Rosolem ${ }^{*}{ }^{, 1}$, Karl Ritz $^{\dagger}$, Heitor Cantarella ${ }^{\ddagger}$, Marcelo V. Galdos ${ }^{\dagger}$, \\ Malcolm J. Hawkesford ${ }^{\S}$, Willian R. Whalley ${ }^{\S}$, Sacha J. Mooney ${ }^{\dagger}$ \\ *São Paulo State University, Botucatu, Brazil \\ ${ }^{\dagger}$ School of Biosciences, University of Nottingham, Leicestershire, United Kingdom \\ ${ }^{\ddagger}$ Center of Soils and Environmental Resources, Agronomic Institute, Campinas, Brazil \\ ${ }^{\S}$ Rothamsted Research, Harpenden, United Kingdom \\ ${ }^{1}$ Corresponding author: e-mail address: rosolem@fca.unesp.br
}

\section{Contents}

1. Introduction

2. Rhizosphere Processes, Root Exudates, Soil Microbiology, and N Cycling

3. N Losses Through Leaching, Nitrous Oxide Emission, and Ammonia Volatilization 213

4. Root Architecture, N Acquisition, and Cycling 218

5. N Cycling in Cropping Systems 224

6. Key Research Challenges 229

Acknowledgments 230

References $\quad 230$

$\begin{array}{ll}\text { Further Reading } & 239\end{array}$

\section{Abstract}

Despite the significant inroads into increasing agricultural productivity in recent decades, nitrogen remains a key limiting factor for crop growth and yield. Though highly variable globally, the amount of reactive $\mathrm{N}$ added yearly onto cropland that is subsequently lost to the environment remains high. As such the interest in agronomic approaches to address this and improve nitrogen use efficiency (NUE) is currently very high. Here, we have shown the combined approaches of management interventions such as no-till, intercropping with leguminous and grass species, use of nitrogen inhibitors, and combined crop-livestock systems offer considerable potential for enhancing NUE and are already being readily deployed in the tropics. Grass species such as Brachiaria in particular have demonstrated enormous potential via their deep root architectures to reduce losses by leaching. However, the potential for increases in NUE through interaction and association of the root systems with the soil microbial community via rhizodeposits remains a major area for future research. Increasingly it is recognized that truly enhancing NUE requires consideration of the whole system. Improving 
NUE is not simply a matter of how much fertilizer is used but also the need for a deeper understanding of the interactions between nutrients, plants, microbes, and soils under specific agronomic situations such as the integrated maize/grass-livestock systems that are now regularly employed in the tropics. This more holistic approach to the management of nitrogen offers considerable benefits that can hopefully be realized not only from an agricultural perspective but also from an environmental and socioeconomic view point.

\section{INTRODUCTION}

Nitrogen is important to all living organisms and is usually the most limiting nutrient for crop yields. Three of the top priorities for soil science research in the 21st century, according to Adewopo et al. (2014), comprise determining: (1) fertilizer use impact on ecosystem functioning, on public health and human well-being, and on nutrient cycling; (2) plant-soilmicroorganism interactions; and (3) soil transport processes. Nitrogen use in agriculture is related to all three priorities. Critically, soil $\mathrm{N}$ not taken up by plants remains available for mineralization, leaching, and volatilization as ammonia or nitrous oxide, which threaten the environment (Austin et al., 2013). To increase nitrogen use efficiency (NUE) of crops, it is important to ensure appropriate plant uptake for crop production and to decrease losses from the agricultural system including immobilization in the soil. For example, it has been estimated that there is only a 33\% recovery of applied nitrogen fertilizer in harvested grains (Raun and Johnson, 1999). Increases in NUE and reductions of surplus applied $\mathrm{N}$ in agriculture should eventually lead to lower $\mathrm{N}$ pollution (Norton et al., 2015). The main soil $\mathrm{N}$ losses occur through nitrate leaching, emissions of nitrous oxide to the atmosphere, ammonia volatilization from plant tissues, and erosion. Ammonia volatilization from the applied fertilizer is an important issue when urea is applied in on the soil surface in no-till systems. Nitrate leaching was estimated in Brazil from trace to $87 \mathrm{~kg} \mathrm{ha}^{-1}$ per year, and losses from fertilizers usually exceed 10-15 kg ha ${ }^{-1}$ per year (Villalba et al., 2014).

NUE can be calculated and expressed in several ways and can be considered at scales from a field/crop to the farm to the country level. Although it is almost impossible to establish an optimal NUE, it is generally accepted that when NUE $<0.5$, there is probably a large opportunity for improvement whereas an NUE $>0.9$ indicates that the efficiency cannot be improved further. An NUE greater than 1.0 indicates $\mathrm{N}$ mining and soil depletion. One practical way to evaluate NUE at a national level is via the partial balance of 
nitrogen ( $\mathrm{kg}$ of $\mathrm{N}$ in grains/kg $\mathrm{N}$ applied). The partial balance of $\mathrm{N}$ in Brazilian agriculture was estimated from 0.65 to 0.70 , while it was 1.3 in the 1990s (Cunha et al., 2011). However, it ranges from 67\% to $248 \%$, showing that in some regions and/or crops $\mathrm{N}$ has been used in excess and in other agricultural ecosystems and regions (mainly in North Brazil) $\mathrm{N}$ application is much lower than crop removal, impoverishing the system. Globally it ranges (for maize) from 0.36 in Vietnam to 2.26 in Argentina (Norton et al., 2015) and has declined in Latin America, India, and China since 1985 (Fixen et al., 2014). It has been estimated that a 2.39\% increase in cereal NUE would lead to $\$ 21$ million savings in $\mathrm{N}$ fertilizers costs (Pires et al., 2015). Hence, an increase in NUE would result not only in environmental and agronomic benefits but also in a substantial economic impact.

The low NUE in many parts of the world has brought the debate of negative environmental impacts of excess $\mathrm{N}$ to the forefront of agriculture matters, and mitigation measures usually include targeting increases in NUE to decrease the input of reactive nitrogen in the planet (Sutton et al., 2013). However, most of the data available on pollution caused by excess $\mathrm{N}$ come from agriculture in temperate climate (Sutton et al., 2013), with relatively little information available on the use of $\mathrm{N}$ in tropical soils and even less on the potential problems associated with low NUE. Although tropical soils can be widely variable, large areas comprise deep and highly weathered soils, and also regions where rainfall is more intense, such as part of Latin America, Africa, and Southeastern Asia. A large proportion of the increase of food production to meet the needs of a growing population in the next decades will take place in Latin America and Africa (FAO, 2009), that is, in tropical soils. This, combined with a likely need for sustainable intensification of agriculture (Snyder et al., 2014), suggests that $\mathrm{N}$ use in agriculture will continue to increase and appropriate management, especially in the tropical environments, will be of the utmost importance. Nitrogen may be transferred to other ecosystems if the cropping system is not properly managed; however, the low NUE frequently reported in the literature worldwide (Dobermann, 2007; Oenema et al., 2015) does not necessarily mean that the nonrecovered $\mathrm{N}$ is lost permanently from the agri-system, because a sizeable portion of the $\mathrm{N}$ inputs may be retained, at least temporarily in the soil organic $\mathrm{N}$.

Nitrogen use in agriculture must be considered under different environments, crops, and cropping systems along with the farmer's socioeconomic profile. NUE in plants is predicated upon the complex interactions between plant physiological properties, root architecture, and soil biological transformations of $\mathrm{N}$, all operating in the framework provided by the soil porous 
architecture. There is currently a knowledge gap concerning the mechanisms involved in these processes for effectively identifying breeding targets for bioengineering of the rhizosphere to enhance NUE and to understand how particular root traits (e.g., dimensions, depth, branching, proliferation, and functioning) affect NUE of specific plants via root-based properties. A better understanding of the role of botanical diversity in such systems, and how this may be manipulated via the nature of the rotation is also important. This will involve exploring the use of intercropping systems and the specific opportunity to introduce additional diversity via multispecies cover crops with complementary belowground functional traits (e.g., mixtures of grasses, legumes, herbs with deep taproots, or prolific lateralization). In some systems, Urochola sp., a genus of grasses used as pasture (also an aggressive weed), is planted along with soybeans and maize to produce a cover crop after harvest. If well managed, the grain crop is not negatively affected by the grass. This would have been considered an agronomic heresy a few years ago, but now it is not only working well but also being increasingly adopted by farmers. Such novel approaches to crop management may be transferred to or adapted in other tropical and subtropical regions to enhance the soil $\mathrm{N}$ budget. It has been shown that crop rotations have important roles in C sequestration and N storage capacity of soils (Castro et al., 2015). Furthermore, crop rotations with legumes can decrease agricultural dependence on mineral $\mathrm{N}$, and grasses with vigorous, deep root systems can prevent $\mathrm{N}$ leaching. In the Brazilian tropics, integrating these cropping systems as crop-livestock and crop-livestock-forest systems has shown considerable economic and environmental promise though $\mathrm{N}$ deficiency has been reported in some areas. The use of plants with deep root systems may help in preventing nitrate leaching and groundwater contamination. Practices considered as paramount in enhancing NUE, such as zero/no tillage, as well as the development of reliable diagnostic tolls of plant nutrition status will be combined with plant breeding to get crops more efficient in $\mathrm{N}$ uptake and use.

\section{RHIZOSPHERE PROCESSES, ROOT EXUDATES, SOIL MICROBIOLOGY, AND N CYCLING}

The key concept we propose is that the plant is a significant governor of the nature of plant/soil interactions at two levels: (i) as the principal delivery agent for energy supply to the soil biota via rhizodeposition (short term) 
and residue (longer term) below ground, which modulates overall biotic activity and functional composition of rhizosphere communities involved in $\mathrm{N}$ uptake from soil and litter as well as biological $\mathrm{N}_{2}$ fixation, and (ii) via more specific subtle, signaling-based interactions which affect particular components of the system, such as nitrification rates (Haichar et al., 2014).

Plant roots deposit a wide range of carbonaceous material into the soil via a process termed rhizodeposition, and the zone of influence arising from this phenomenon is known as the rhizosphere (e.g., Raaijmakers et al., 2009; York et al., 2016). This can represent up to $20 \%$ of total C fixed by the associated plant (Jones et al., 2009). Such material ranges from biochemicals including soluble low-molecular weight compounds through intermediate oligopolymers to complex polymers, to tissues ranging from entire single cells (in the vicinity of the root tip) to sloughed cortex arising from physical damage or senescence. These materials fundamentally represent an energy source to soil organisms and as such there is generally a proliferation of microbes, and then an associated succession of micro- and mesofauna in the vicinity of roots. In turn, rhizosphere-associated microbial communities can affect the amounts and nature of rhizodeposited materials (Jones et al., 2004; Kuijken et al., 2015). The resultant increased microbial activity stimulated by rhizodeposits then affects many processes in the rhizosphere (Haichar et al., 2012). Of particular pertinence to NUE is a general acceleration nutrient cycling, which can result in an enhanced provision of nitrogen to plants, via processes of mineralization. Such actions can lead to so-called rhizosphere priming effects of N (Kuzyakov, 2010; Meier et al., 2017; Zhu et al., 2014), where there is an apparent stimulation of the decomposition of otherwise recalcitrant soil organic matter. This arises as a result of the microbial biomass "mining" $\mathrm{N}$ from particular sources of $\mathrm{OM}$ in response to the availability of additional energy (Murphy et al., 2015). Zhu et al. (2014) showed distinct increases in enzyme activity profiles associated with rhizodeposition which were different between soybean and sunflower, suggesting that not all species induce such effects to a similar extent, which offers the potential that specific species may be more or less effective in terms of priming $\mathrm{N}$ release from soil organic matter.

Certain bacteria and algae are able to fix $\mathrm{N}_{2}$, some in a free-living state and others in symbiotic associations of varying intimacy with other organisms, particularly green plants. In an agricultural context, the mutualistic association between legumes and some bacteria including members of the orders Rhizobiales and Burkholderiales are of particular significance since 
substantial quantities of $\mathrm{N}$ can be fixed and effective yields of protein-rich grain or herbage obtained without additional $\mathrm{N}$ fertilization of crop or soil. These symbioses are generally so effective due to the highly intimate relationship between plant host and bacterial symbiont where the latter infects the hosts' roots and there is an endogenous transfer of fixed $\mathrm{N}$ into the plant tissues. Hence, legumes can play a key role in importing $\mathrm{N}$ into agricultural soil systems, and in particular, where they are used as cover crops or green manures, where fixed $\mathrm{N}$ is not removed from the field zone in a harvested crop. As such, the plant residues are relatively $\mathrm{N}$-rich. Release of $\mathrm{N}$ from these sources is then contingent of the mineralization of organic $\mathrm{N}$ via the biotically mediated processes rehearsed elsewhere in this review.

The release of plant growth substances like phytohormones and vitamins (Faure et al., 2009) and the promotion of nonsymbiotic N2-fixing microorganisms are also beneficial effects of the microbial community in the rhizosphere. Interactions between plant roots and the beneficial bacteria within their rhizosphere shape the bacteria community composition, as well as enhancing plant growth and plant pathogen defense. Associative rhizosphere microbes interact with plants in a variety of modes ranging from neutral, through beneficial to antagonistic with respect to the growth or health of the plant. These relationships are not deemed symbioses as such, since it is unclear as to the extent to which both partners "benefit" directly from such relationships compared with true symbiotic associations discussed earlier. There is a very large body of literature that considers the potential plant growth-promoting characteristics of such microbes, particularly the so-called plant growth-promoting rhizobacteria (PGPR), with decades of research seeking to understand the mechanisms behind such effects, and optimize their application to stimulate plant growth (e.g., Avis et al., 2008; Bishnoi, 2015; Lucy et al., 2004). PGPR effects of direct relevance to NUE are essentially twofold:

(i) Via production of plant growth-promoting substances (phytohormones). The production of such compounds by bacteria including auxins, cytokinins, gibberellins, ethylene, and abscisic acid has been reported for many species, but direct evidence that such production in the soil situation affects plant growth is actually scarce (Spaepen et al., 2009). This is partly due to the difficulty of discriminating between such compounds derived from the plant as opposed to an associated microbe. Among the strongest evidence is for auxin-induced effects upon root morphology by Azospirillum brasilense (Dobbelaere et al., 1999). Effects upon cell division and differentiation can then lead to changes in root system architecture, which can consequently 
affect nutrient uptake via the effective volume of soil explored by the roots (Verbon and Liberman, 2016; Walker et al., 2003).

(ii) Via biological $\mathrm{N}$ fixation. A variety free-living $\mathrm{N}$-fixing bacteria may proliferate in the rhizosphere or even endophytically within roots (Elmerich and Newton, 2007), and the $\mathrm{N}$ that they fix can be transferred to the associated plants. These so-called associative diazotrophic relations are deemed more significant where plants such as sugar cane and maize are involved, possibly due to the higher rates of carbon delivery to the rhizosphere in these species. Based on the evaluations of over 20 years of field applications of A. brasilense and Azospirillum lipoferum across a range of countries, Okon and Labanderagonzalez (1994) concluded that application of Azospirillum can increase crop growth and yield by 5\%-30\% depending on soil and climate conditions. These effects are generally modest but certainly significant, especially in the context of inherently low-production systems. Hungria et al. (2016) recently demonstrated 5\%-20\% increases in growth of Brachiaria species growing in degraded pastures following inoculation with two notably effective strains of $A$. brasilense. There remains optimism that a more detailed understanding of the factors which govern such relationships may lead to more effective manipulation and increase in the amounts of $\mathrm{N}$ fixed and transferred to host plants (Baldani and Baldani, 2005; Carvalho et al., 2014).

Plants thus recognize and actively respond specifically to soil microbial communities by producing signals that modulate colonization (Haichar et al., 2014). Root exudates also function as chemoattractants for soil bacteria, in a behavior known as chemotaxis. Bacteria chemotactic responses to root exudates play a relevant ecological role in plant-associated bacteria, and constitute the first step in initiating communication between plant roots and microbes. Legume roots, for example, exude flavonoids into the soil which activate the expression of nod genes in rhizobia. These nod genes are responsible for the synthesis of nod factors, which are perceived by a receptor in the legume host and trigger the curling of root hairs around the invading rhizobia, the entry of rhizobia into the plant through infection threads, and nodule development (Cullimore et al., 2001). Such infections then underpin the resultant $\mathrm{N}$-fixing mutualism that develops between symbiotic bacteria and their legume hosts.

The amount of nitrogen in the soil also affects root-microbe interactions. In a study evaluating the effects of different $N$ fertilizer rates on NUE in maize, Zhu et al. (2016) reported that when maize was supplied with increasing amounts of $\mathrm{N}$, roots secreted more sugars, sugar alcohols, and 
phenolics, which subsequently altered the soil microbial community structure and abundance. High $\mathrm{N}$ rates appeared to increase the activity of ammonia-oxidizing and denitrification bacteria leading to a decrease in NUE. These results show that $\mathrm{N}$ added as fertilizer can modify the composition and abundance of root exudates and subsequently affect the rhizosphere microbial communities.

Certain plants can inhibit nitrification in the soil by releasing root exudates, in a process called biological nitrification inhibition (BNI). Inhibition of nitrification is likely to be part of an adaptation mechanism to conserve and use $\mathrm{N}$ efficiently in natural systems that are $\mathrm{N}$ limiting. Subbarao et al. (2007) identified a wide range of BNI capacity in a number of species including tropical and temperate pastures, cereals, and legumes. Among the tested cereal and legume crops, sorghum, pearl millet, and groundnut showed detectable BNI in root exudates, and among pasture grasses, Brachiaria humidicola and Brachiaria decumbens showed the highest BNI capacity. Subbarao et al. (2009) discovered an effective nitrification inhibitor, "brachialactone," in the root exudates of the tropical forage grass B. humidicola, which contributed to $60 \%-90 \%$ of the inhibitory activity released from the roots of this tropical grass. Brachialactone appears to block both AMO and hydroxylamine oxidoreductase enzymatic pathways in Nitrosomonas. Release of this inhibitor is a regulated plant function, triggered and sustained by the availability of $\mathrm{NH}_{4}{ }^{+}$in the root environment (Subbarao et al., 2009). It has been demonstrated that sorgoleone, a $p$-benzoquinone exuded from sorghum roots, has an inhibitory effect on Nitrosomonas sp. activity, contributing significantly to BNI in sorghum (Subbarao et al., 2013). BNI has also been identified in rice (Sun et al., 2016; Tanaka et al., 2010) and in Brassicaceae crops (Brown and Morra, 2009). By increasing the ammonium to nitrate ratio in the soil, BNI has the potential to reduce environmental losses of nitrogen by $\mathrm{N}_{2} \mathrm{O}$ emissions. In a laboratory incubation study, Ishikawa et al. (2003) evaluated the ability of three pasture species, B. humidicola, B. decumbens, and Melinis minutiflora to inhibit nitrification. Among the species studied, B. humidicola inhibited nitrification and maintained $\mathrm{NH}_{4}-\mathrm{N}$ in soil to a much greater extent than the other two species. The ammonia-oxidizing bacteria populations and $\mathrm{N}_{2} \mathrm{O}$ emission from the soil were significantly lower in the soils where $B$. humidicola had been grown compared with the other two species.

While the majority of biotic rhizosphere interactions are considered from the perspective of microbial communities (i.e., bacterial and fungal), Bonkowski et al. (2009) point out that soil fauna also interact beneficially 
with plant roots to a greater extent than is generally considered, and stress that soil food webs are not necessarily principally driven by aboveground inputs. Many biotically mediated rhizosphere interactions operate in a general sense, and there may be opportunities to manipulate them by affecting root exudation properties of crop plants by selective breeding or genetic manipulation.

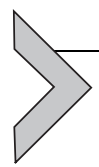

\section{N LOSSES THROUGH LEACHING, NITROUS OXIDE EMISSION, AND AMMONIA VOLATILIZATION}

Nitrate leaching is an important way nitrogen is lost from agricultural soils (Cameron et al., 2013). Nitrate- $\mathrm{N}$ is the inorganic $\mathrm{N}$ form that usually prevails in aerated soils because of the relatively rapid nitrification, following amide or ammonium fertilizer application or organic matter mineralization. The highly soluble $\mathrm{NO}_{3}{ }^{-}$ion is little retained by the predominantly negatively charged soil particles and tends to move in the soil with water. In periods of excess water moving through the soil profile and insufficient plant uptake, $\mathrm{N}$ losses may be significant. Nitrate leaching combined with runoff losses is in order of $95 \mathrm{Tg}_{\text {year }}{ }^{-1}$ of $\mathrm{N}$ (Sutton et al., 2013). In addition to the economic impact for farmers, the $\mathrm{NO}_{3}{ }^{-}$transferred from the soil to streams, ground water, and water bodies is a major environmental concern (Oenema et al., 2015). It is estimated that agricultural soils provide 39-95 $\mathrm{Tg}^{\text {year }}{ }^{-1}$ of $\mathrm{N}$ that are transferred to fresh waters (Sutton et al., 2013). Legislation controlling the use of $\mathrm{N}$ fertilizer is in place in several countries (Oenema et al., 2015). Therefore, there are plenty of reasons for farmers and the society to look for ways to reduce $\mathrm{NO}_{3}{ }^{-}$leaching losses.

However, in countries such as Brazil $\mathrm{NO}_{3}{ }^{-}$leaching losses and water contamination seem not to be a major problem as most data suggest (Cantarella, 2007; Ghiberto et al., 2009, 2015). Among the reasons are that $\mathrm{N}$ fertilizer rates are relatively small compared with those used in Europe, USA, and China, farmers usually split $\mathrm{N}$ applications, and deep oxisols have positively charged clay particles in the subsoil, especially at low $\mathrm{pH}$ (Lopes and Guilherme, 2016). However, as the average crop yields increase in Brazil, so are the amounts of $\mathrm{N}$ fertilizers used, and consequently increased $\mathrm{NO}_{3}{ }^{-}$ leaching losses have been reported (Bortolotto et al., 2012; Cantarella et al., 2003).

Nitrogen leaching, at least in tropical oxisols, may not be directly related to the rate of fertilizer applied or rainfall (Fig. 1), but a more likely relationship of $\mathrm{N}$ loss would be with soluble $\mathrm{N}$ species contents in the soil profile, 

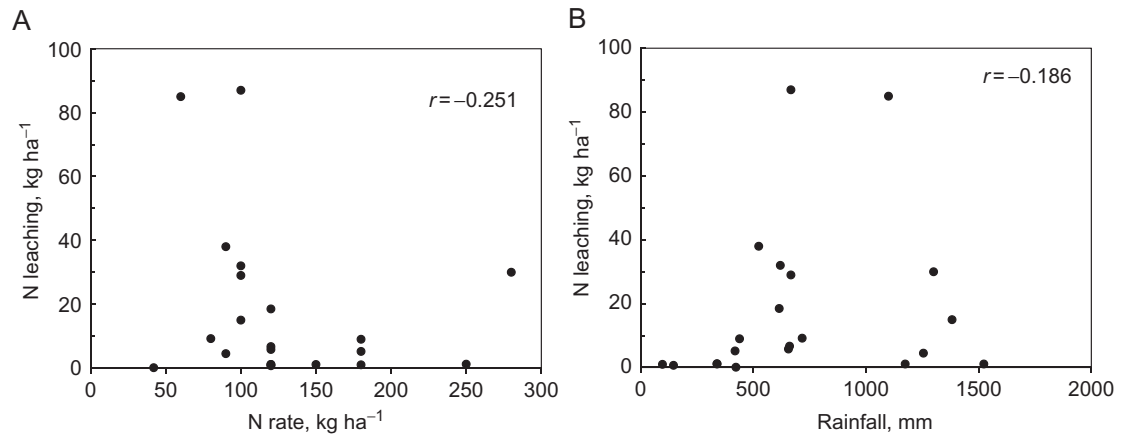

Fig. 1 Pearson correlation of $\mathrm{N}$ applied rate $(\mathrm{A})$ and rainfall $(\mathrm{B})$ with $\mathrm{N}$ leaching in 21 Brazilian oxisols cropped to common beans (Phaseolus vulgaris), maize (Zea mays), sugarcane (Sacharum officinarum), black oats (Avena strigose), coffee (Cofea arabica), and Brachiaria (Urochloa sp.), fertilized with ammonium sulfate or urea. Adapted from data compiled by Villalba, H.A.G., Leite, J.M., Otto R., Trivellin, P.C.O., Fertilizantes nitrogenados: novas tecnologias. Informações Agronômicas 148, 2014, 12-18, http:// www.ipni.net/publication/ia-brasil.nsf/issue/IA-BRASIL-2014-148.

including those derived from soil organic $\mathrm{N}$ mineralization (Ghiberto et al., 2009). Studies considering area-scaled $\mathrm{NO}_{3}{ }^{-}$losses have shown that increasing $\mathrm{N}$ rates enhances yields, but sometimes increases $\mathrm{N}$ loss with high fertilizer rates (Zhou and Butterbach-Bahl, 2014); however, when leaching losses are considered in a yield-scaled basis (Zhao et al., 2016), leaching responds exponentially to $\mathrm{N}$ surplus (estimated as $\mathrm{N}$ application rate minus aboveground crop N uptake). Precipitation and/or drainage water may be important when rainfall or water availability is higher than the historical average (Zhao et al., 2016). It has been generally stated that lowering $\mathrm{N}$ rates to reach $90 \%$ of the yield potential in maize would substantially decrease $\mathrm{N}$ leaching (Zhao et al., 2016; Zhou and Butterbach-Bahl, 2014), but could a 10\% yield loss be accepted in a hungry world?

Hence, improving NUE in agricultural systems is not just a matter of using more or less fertilizers; it requires a deep understanding on how nutrients, plants, and soil interact in a cropping system to avoid losses. Therefore, leaching losses can be minimized by good agronomic practices (Reetz, 2016) that prevent $\mathrm{N}$ surplus in the soil profile; the introduction of catch crops and smart crop rotations and arrangements in time and space may be good options not only to reduce $\mathrm{NO}_{3}{ }^{-}$leaching but also to increase biomass yield per unit area.

Nitrification inhibitors are also used to delay nitrification and decrease $\mathrm{NO}_{3}{ }^{-}$leaching losses (Chien et al., 2009; Liu et al., 2013; Snyder et al., 2014; Trenkel, 2010). The most common compounds in the market are 
dicyandiamide (DCD), 3,4-dimethylpyrazole phosphate (DMPP), and nitrapyrin (Trenkel, 2010). Effects of nitrification inhibitors on yields are usually small but consistent only in situations where $\mathrm{NO}_{3}{ }^{-}$leaching losses are potentially high (Linquist et al., 2013; Abalos et al., 2014).

Natural compounds present in some plant species may also reduce nitrification rates in soils. Glucosinolates-containing plants of the Brassica genus may inhibit nitrification in soils (Brown and Morra, 2009) and maintain N in ammonium form for some time. As mentioned earlier, several species, including sorghum, groundnut, pearl millet, and Brachiaria grasses, produce exudates capable of inhibiting nitrification (Subbarao et al., 2006, 2009). B. humidicola seems to be the species with the higher potential for that and a nitrification inhibitor, brachialactone, has been isolated (Subbarao et al., 2009). This has been demonstrated in low $\mathrm{N}$ environments, and may deserve further investigation under agricultural conditions. However, the effect of these biological nitrification inhibitors is not always clear. Kölln et al. (2016) found that the root extracts of B. humidicola increased the initial growth of sugarcane plants but such an effect may as well be due to plant growth-promoting substances present in the root extracts because DCD, a synthetic nitrification inhibitor, did not produce the same effect. Castoldi et al. (2013) measured the concentrations of inorganic $\mathrm{N}$ at several time intervals after desiccating plants of humidicola (B. humidicola, sin. Urochloa humidicola), palisade grass (Brachiaria brizantha, sin. Urochloa brizantha), signalgrass (B. decumbens, sin. Urochloa decumbens), and ruzigrass (Brachiaria ruziziensis, sin. Urochloa ruziziensis) with herbicide. Total $\mathrm{N}$ and ammonium concentrations were higher in the rhizosphere than in nonrhizosphere soil, and $\mathrm{pH}$ was lowest in the rhizosphere of $B$. humidicola, which could result in nitrification inhibition. Although B. humidicola seemed to have inhibited nitrification in the rhizosphere, little variation in nitrate and ammonium in the soil indicated that the inhibitory effect was not high. In addition, it has been observed that nitrification was influenced in the rhizosphere of B. brizantha; however, this effect was not high enough to modify the $\mathrm{N}-\mathrm{NH}_{4}{ }^{+}$level in the bulk soil (Fernandes et al., 2011). Therefore, it was concluded that in soil with abundant $\mathrm{N}$ supply none of the Brachiarias studied caused a significant effect on nitrification (Castoldi et al., 2013).

Ammonia volatilization losses from agricultural and livestock systems are estimated in $37 \mathrm{Tg}_{\text {year }}{ }^{-1}$ of $\mathrm{N}$ (Sutton et al., 2013). The extent of losses depends, among several factors, on the $\mathrm{N}$ source and method of application, soil characteristics, and temperature and moisture conditions as shown by the classic studies of Ernst and Massey (1960) and Terman (1979). The calculated average $\mathrm{NH}_{3}$ volatilization loss from synthetic fertilizers in 
the world is $14 \%$ (Bouwman et al., 2002). Soil $\mathrm{pH}$, by controlling the balance between $\mathrm{NH}_{4}{ }^{+}$and $\mathrm{NH}_{3}$ species in the soil solution, strongly affects $\mathrm{NH}_{3}$ losses from ammonium-containing fertilizers, but urea, which is the dominant $\mathrm{N}$ source in the world market (Heffer and Prud'homme, 2013), is lost even in acidic soil when surface-applied. In tropical soils, due to high temperatures and moisture, $\mathrm{NH}_{3}$ losses exceeding $40 \%$ of the surface-applied urea $\mathrm{N}$ have been reported, especially under no-till or perennial crops where plant residues are kept on the soil surface (Cantarella et al., 2003; Lara Cabezas and Souza, 2008). Incorporation of urea into the soil by mechanical means or water is an efficient way to reduce $\mathrm{NH}_{3}$ losses: Rochette et al. (2013) found that losses were negligible when urea was placed at a depth $\geq 7.5 \mathrm{~cm}$, and Holcomb et al. (2011) observed that $14.9 \mathrm{~mm}$ of irrigation water decreased loss by about $90 \%$. However, incorporation is not always possible or feasible, as in perennial crops and sugarcane harvested without burning, where a thick mulch remains on the soil (Cantarella et al., 2008), or even in very large fields where operation timing is an issue. In these cases, $\mathrm{N}$ sources not subject to volatilization losses would be preferable, but low cost and market availability of urea may drive farmers to use this fertilizer, despite the potentially lower NUE.

Ammonia volatilization losses from urea may be decreased by treating this fertilizer with urease inhibitors (Bremner, 1995; Chien et al., 2009; Watson et al., 2008). Several compounds have been tested for this purpose but the most effective to reach the market is $\mathrm{N}-(n$-butyl)thiophosphoric acid triamide (NBPT) and many studies have reported reduction of $\mathrm{NH}_{3}$ losses up to $70 \%$ (Chien et al., 2009; Silva et al., 2017; Suter et al., 2013; Trenkel, 2010), but less under excess of crop residues, such as sugarcane plant residues (Cantarella et al., 2008). Recently, a formulation containing NBPT and $\mathrm{N}$-(n-propyl) thiophosphoric triamide was introduced in the market (Li et al., 2015).

Herbicides are the main tool used to desiccate cover crops in integrated agricultural systems and crop rotations under no-tillage, and this may increase both root exudation of $\mathrm{N}$ compounds (Damin et al., 2010) and $\mathrm{N}$ loss by shoots of signalgrass (Damin et al., 2008). The plant developmental stage with the highest $\mathrm{NH}_{3}-\mathrm{N}$ emission potential is senescence, because $\mathrm{NH}_{3}-\mathrm{N}$ concentration is increased as protein is degraded (Marstorp, 1995), and the amount of ammonia volatilized is proportional to the leaf $\mathrm{N}$ concentrations and temperature (Whitehead et al., 1988). Signalgrass and humidicola left $74 \%$ and $75 \%$ of their lost $N$ during senescence available in the soil, respectively; palisade grass left 54\% and ruzigrass $64 \%$ (Castoldi et al., 2014). Most of the $\mathrm{N}$ was lost as $\mathrm{NH}_{3}-\mathrm{N}$, accounting for 
$30 \%-80 \%$ of the $\mathrm{N}$ total loss. However, the total $\mathrm{N}$ losses from the soil-plant system after grass desiccation ranged from $0.5 \%$ to $1.4 \%$ of the total $\mathrm{N}$ in the system, or 0.8 to $2.0 \mathrm{~g} \mathrm{~m}^{-2} \mathrm{~kg}^{-1}$ of dry matter. Considering a dry matter yield of $6 \mathrm{tha}^{-1}, \mathrm{NH}_{3}-\mathrm{N}$ losses would range from 4.8 to $12.0 \mathrm{~kg} \mathrm{ha}^{-1}$ (Castoldi et al., 2014).

Denitrification is also an important way $\mathrm{N}$ is lost from the soil system, in the order of $25 \mathrm{Tg}_{\text {year }}{ }^{-1}$ of N (Billen et al., 2013; Sutton et al., 2013). Denitrification losses are relevant in soils under anaerobic conditions, such as waterlogged rice fields, or within soil aggregates in aerated soils; most $\mathrm{N}$ is lost as $\mathrm{N}_{2}$ but small amounts of $\mathrm{N}_{2} \mathrm{O}$ are also formed (Cameron et al., 2013). NUE may be highly improved in poorly drained soils with appropriate fertilizer choice, time of application, and placement (Linquist et al., 2013), but in aerated soils subject to variable and partial anaerobism management practices to avoid losses are not always easy established. Actually, it is also difficult to estimate actual $\mathrm{N}_{2}$ losses in well-drained soil (Hofstra and Bouwman, 2005).

Although $\mathrm{N}_{2} \mathrm{O}$ losses are of relatively little relevance to the $\mathrm{N}$ balance in agriculture, usually only around $1 \%$ of the fertilizer $\mathrm{N}$ applied, recently much attention has been devoted to it because of the strong greenhouse effect of this gas, about 300 times greater than that of $\mathrm{CO}_{2}$, and because agriculture is the main anthropogenic source of $\mathrm{N}_{2} \mathrm{O}$ (Oenema et al., 2014; Snyder et al., 2014). Nitrous oxide is also produced under aerobic conditions during nitrification, among other processes (Müller et al., 2014). Soares et al. (2016) found that nitrification was the main source of $\mathrm{N}_{2} \mathrm{O}$ loss in a sugarcane field in Brazil. In their study, the $\mathrm{N}_{2} \mathrm{O}$ emissions from calcium nitrate were the same as that of the unfertilized control.

Practices that decrease $\mathrm{N}_{2} \mathrm{O}$ emission in agriculture may have little significance for increasing NUE but may be important in preventing global warming (Sutton et al., 2014). As $\mathrm{N}_{2} \mathrm{O}$ is generated by natural soil processes such as nitrification and denitrification, avoiding excess $\mathrm{N}$ in the soil when plants cannot take it up decreases the emission of this gas (Snyder et al., 2014). Therefore, crop management strategies to decrease leaching loss and increase NUE will also decrease $\mathrm{N}_{2} \mathrm{O}$ emission (Snyder et al., 2009). Nitrification inhibitors can also reduce $\mathrm{N}_{2} \mathrm{O}$ emission from fertilizers applied to soil. A recent meta-analysis of the effect of DCD and DMPP on $\mathrm{N}_{2} \mathrm{O}$ emission (Gilsanz et al., 2016) found an inhibitory effect of 40\%-42\%. In a study with sugarcane in Brazil under field conditions and 3 years of observation, DCD and DMPP reduced $\mathrm{N}_{2} \mathrm{O}$ emissions from urea by $85 \%-95 \%$ (Soares et al., 2015, 2016). Although it is well established that nitrification 
inhibitors have a significant effect in reducing $\mathrm{N}_{2} \mathrm{O}$ emissions, it is unlikely that farmers will pay the extra price of the treatment if there are no yield benefits, because the $\mathrm{N}$ not emitted (preserved in the soil) is usually less than $1 \%$ of the $\mathrm{N}$ fertilizer applied.

Sometimes urease and nitrification inhibitors are jointly added to urea fertilizer to decrease leaching and volatilization losses, but some recent studies have shown that nitrification inhibitors increase $\mathrm{NH}_{3}$ losses by maintaining high soil $\mathrm{pH}$ due to urea hydrolysis, thus reducing the benefit of the urease inhibitor (Frame, 2017; Kim et al., 2012). In a study under controlled conditions, the mixture of both inhibitors caused the $\mathrm{NH}_{3}$ losses to be like that of the nontreated urea (Soares et al., 2012). Therefore, care must be taken with the combination of additives to have the desired benefit of increasing NUE.

\section{ROOT ARCHITECTURE, N ACQUISITION, AND CYCLING}

Roots are essential for $\mathrm{N}$ acquisition and $\mathrm{N}$ uptake is required throughout plant development, with the likely exception of maturation, when canopy senescence may enable internal remobilization processes to dominate. The plant $\mathrm{N}$ uptake capacity needs to be matched to demand for crop growth, and will be highest during canopy formation. Specific growth stages, for example, seed or fruit set, may have high demands for $\mathrm{N}$; however, as indicated earlier, this may be met by internal remobilization and repartitioning.

Soil organic matter tends to accumulate in the upper soil layers. Therefore, the shallow rooting system of crops exploits not only the inorganic $\mathrm{N}$ in the soil surface layer but also the $\mathrm{N}$ derived from organic matter $\mathrm{N}$ mineralization. The highly soluble and mobile forms of $\mathrm{N}$, especially $\mathrm{NO}_{3}{ }^{-}-\mathrm{N}$, that tends to move to the lower soils layers with rain or irrigation water, may be lost if there are no active roots to take up the nutrient. Roots must also be able to exploit the available $\mathrm{N}$ in the soil at different depths. Shallow and profuse rootscan effectively intercept surface-applied fertilizer, while deeper roots may scavenge $\mathrm{N}$ leaching down the soil profile and other $\mathrm{N}$, for example, mineralization of crop residues, occurring at depth. Mineralization may lead to localized N supplies which will also influence root proliferation (Drew et al., 1973).

Predicting the optimum root ideotype for a crop in any environment requires knowledge of soil profiles and agronomic practice, particularly regarding $\mathrm{N}$ fertilization. Equally important is the knowledge of climatic 
conditions, and particularly patterns of rainfall. The properties of the soil are paramount and will strongly influence root proliferation and ideally ideotypes will be adapted to cope with different soil conditions. At present our understanding of root proliferation and rooting depth in the field is empirical and guided by a relatively few number of field studies (Fan et al., 2016; Ober et al., 2014). The explanations to account for deep rooting are currently speculative. However, the importance of the soil pore network to allow and facilitate root elongation to depth has been identified a key aspect of soil management with important implications for deep rooting (Gao et al., 2016; White and Kirkegaard, 2010); this is because with almost all soils soil strength increases rapidly with depth. In the surface layers of soil, which unless damaged, tend to be low in soil strength, soil nutrient status is heavily implicated in root proliferation and branching (Chapman et al., 2011). While some effects of soil structure at delivering both water (Bao et al., 2014) and nutrient (Chapman et al., 2011) to the roots, and the implications for branching have been studied in laboratory systems in some detail, the application of this work to the field environment remains a significant and important challenge, with significant potential rewards. Important opportunities exist in intercropping systems, where root interactions between different crops can increase the access of $N$ (Drew et al., 1973) and P (Zhang et al., 2016). Even in monoculture, roots of different species respond differently to soil nutrient status, for example, wheat and maize respond to increased $\mathrm{P}$ by proliferation, whereas other crop species (e.g., soybean) do not (Lyu et al., 2016).

In many parts of the world chemical constraints to root growth such as subsoil acidity and or calcium deficiency are also important (Ritchey et al., 1995). Soil acidity can be corrected easily by liming, but overcoming subsoil acidity is more complex because of the low solubility of lime. Quaggio et al. (1985) found that deepening the root system caused a significant increase in $\mathrm{N}$ uptake and corn grain yield compared with unlimed plots (Quaggio et al., 1991), indicating that effective control of subsoil acidity may enhance NUE. However, in high clay or high CEC soils the effect of liming to correct subsoil acidity may be slow, especially in no-till systems where the neutralizing material is not incorporated in the soil (Costa and Rosolem, 2007). Thus, phosphogypsum may be used to ameliorate subsoil acidity, alone or in combination with lime, which neutralizes soil acidity in the upper soil layers. In a review article by Ritchey et al. (1995) there are several examples of decreased $\mathrm{NO}_{3}{ }^{-}$concentration in the subsoil which correspond with an increase in crop $\mathrm{N}$ uptake and grain yield resulting from phosphogypsum 
application to acidic oxisols of Central Brazil, thus substantiating the indirect effect of the use of this by-product on NUE.

Cover crops with vigorous root systems, when introduced in cropping systems, can avoid $\mathrm{N}$ losses by taking up high amounts of $\mathrm{N}$, having $\mathrm{C} / \mathrm{N}$ ratios that facilitate a balance between mineralization and immobilization, or even facilitating the synchrony of mineralization with $\mathrm{N}$ uptake by the subsequent crop (Lara Cabezas et al., 2004). Legume cover crops add $\mathrm{N}$ to the system, offsetting losses, and grasses, while not adding $\mathrm{N}$ to the system may prevent losses by taking $\mathrm{N}$ up and immobilizing it in the biomass. Grasses with vigorous, extensive root systems such as signal grass (B. decumbens), sorghum (Sorghum bicolor), finger millet (Eleusine coracana), chicory (Cichorium intybus), black mucuna (Stizolobiun aterrinnum), blue lupin (Lupinus angustifolius), and fodder radish (Raphanus raphanistrum) can grow roots deep into the soil profile, whereas species as pigeon pea (Cajanus cajan), sun flower (Helianthus annuus), Sunn hemp (Crotalaria juncea), showy crotalaria (Crotalaria ochroleuca), and forage turnip (Raphanus sativus) are able to penetrate compacted soil layers. Other species as pearl millet (Pennisetum americanum), palisade grass, and ruzigrass have vigorous, dense root systems and can penetrate compacted soil layers. Silva and Rosolem (2003) observed that pearl millet accumulated more $\mathrm{N}$ than lupins and black oats in a compacted soil because it could explore deeper soil layers.

$\mathrm{N}$ uptake is related to root growth because deep-rooted species explore large soil volumes and have access to a large amount of $\mathrm{N}$, facilitating greater uptake (Barber and Cushman, 1981). Considering the length of a growing season, or time of growth of a cover crop, even a low root density may be enough for the uptake of significant amounts of $\mathrm{N}$ that otherwise would be leached and lost to the environment (Robinson, 1986), but as noted earlier, roots tend to proliferate in N-rich soil patches, facilitating the recovery of the nutrient from deeper soil layers. Hence, catch/cover crops can deplete $\mathrm{N}$ from parts of the soil profile not reached by shallow-rooted crops. Differences in soil nitrate exploration by species with deep, dense rooting are of special interest not only for environmental protection but also in increasing $\mathrm{N}$ fertilizer use efficiency, since $\mathrm{N}$ in deep soil layers is more prone to leaching than in upper soil layers (ThorupKristensen and Nielsen, 1998). Therefore, $\mathrm{N}$ taken up from deeper soil layers by a cover crop may be used as a tool in avoiding $\mathrm{N}$ leaching and enhancing NUE.

The $\mathrm{C} / \mathrm{N}$ ration of soil organic matter tends to be constant around 10; hence, the $\mathrm{N}$ and $\mathrm{C}$ stocks in the soil profile are correlated. Furthermore, 
there is evidence that $\mathrm{C}$ and $\mathrm{N}$ accumulation in soils under zero tillage is enhanced by the introduction of legumes in the rotation (Boddey et al., 2010), and it has been shown that improved root growth of cover crops increased both particulate $\mathrm{C}$ and $\mathrm{N}$ fractions in the soil (Rosolem et al., 2016).

While soil remediation through chiseling or cover crops can potentially contribute to improvements in soil structure and rootability, the effects on nitrate leaching are different in each case. No-till can decrease $\mathrm{NO}_{3}{ }^{-}$ leaching compared with conventional tillage due to a lower organic matter mineralization rate and/or a higher denitrification (Mkhabela et al., 2008). It is also likely that the differences in the architecture of the pore networks influence this (e.g., Mangalassery et al., 2014), though the effect on $\mathrm{N}$ transport has yet to be demonstrated in the literature. Soil organic matter mineralization may be responsible for a large part of the $\mathrm{N}$ leached in some agricultural cropping systems (Fernandes et al., 2006; Ghiberto et al., 2009). Furthermore, the decreased leaching under NT compared with chiseling may be due to a high water flow at depth and increased $\mathrm{NO}_{3}{ }^{-}$concentration (higher SOM mineralization) with soil mobilization (Rekha et al., 2011). However, the network of biopores formed in the soil profile under no-till may cause greater losses of $\mathrm{N}$ by leaching (Paul and Clark, 1989). Mangalassery et al. (2014) showed increased $\mathrm{N}_{2} \mathrm{O}$ emissions under zero till but a reduced overall global warming potential, and modeling across a range of soil biophysical properties, they found that the morphology of the soil pore network accounted for most of the variation in GHG fluxes as opposed to soil carbon or moisture content.

Root proliferation is important also in capturing $\mathrm{N}$ from organic sources, both in interspecific competition and in competition with microbes (Hodge, 2004), but correlations between $\mathrm{N}$ captured from simple $\mathrm{N}$ sources, such as $\mathrm{NO}_{3}$ and root length densities are often weak. Thorup-Kristensen (2001) also observed that the amount of nitrate left in the topsoil $(0-0.5 \mathrm{~m})$ was only weakly correlated with a few of the measured plant and root parameters, whereas the subsoil $(0.5-1.0 \mathrm{~m})$ nitrate concentration was clearly negatively correlated to root intensity, but showed even stronger correlations to more simple estimates of rooting depth. In the deepest soil layer measured $(1.0-1.5 \mathrm{~m})$, nitrate concentration in the soil solution was decreased from $119 \mu \mathrm{g} \mathrm{L}^{-1}$ without a catch crop, to $61 \mu \mathrm{g} \mathrm{L}^{-1}$ under Italian ryegrass and to only $1.5 \mu \mathrm{g} \mathrm{L}^{-1}$ under fodder radish. Sapkota et al. (2012) also showed that the rate of soil $\mathrm{N}$ depletion is highly correlated with the size of fodder radish rooting system. 
Cruciferous catch crops have deeper rooting than winter rye and, accordingly, deplete the soil of nutrients more effectively (Grindlay, 1995; Thorup-Kristensen, 1993). While monocot species usually have high root densities in the upper soil layers, many dicot species have a high root density deeper in the soil profile (Kutschera and Lichtenegger, 1982), and hence would be more efficient in acquiring $\mathrm{N}$ from deeper soil layers (Thorup-Kristensen, 2001).

Comparing $\mathrm{N}$ uptake and root characteristics of eight Gramineae species (rice, spring wheat, barley, oat, maize, sorghum, redtop, and orchardgrass) and seven Leguminosae species (soybean, field bean, adzuki bean, lupin, pea, alfalfa, and red clover), Shinano et al. (1994) concluded that in Gramineae $\mathrm{N}$ uptake is correlated with crop growth rate, but not with root size, whereas in Leguminosae $\mathrm{N}$ accumulation is correlated with root weight and crop growth rate only during the early vegetative stage. Although Shinano et al. (1994) reported that the accumulation of nitrogen in the plant was basically controlled by shoot growth during the vegetative stage in both families. Thorup-Kristensen (2001) found that none of the measurements made aboveground of Italian ryegrass and fodder radish or in the upper soil layers were well related to subsoil nitrate depletion. Hence, the effectiveness of a cover crop in avoiding losses by leaching depends on its ability to accumulate large amounts of $\mathrm{N}$ and root colonization deep in the soil profile.

Important differences were also determined among grasses, since $\mathrm{NO}_{3}{ }^{-}$ leaching was similar for ruzigrass and grain sorghum cropped in the fall/ winter, but was decreased by triticale, likely due to both high $\mathrm{N}$ uptake and subsequent $\mathrm{N}$ immobilization in the straw. Furthermore, millet and sorghum resulted in the lowest $\mathrm{N}$ leaching because the $\mathrm{NO}_{3}{ }^{-}$solution concentration was low during soybean growth after these species. In the spring, Sunn hemp and grain sorghum resulted in higher $\mathrm{NO}_{3}{ }^{-}$leaching because more $\mathrm{N}$ was accumulated where these species were present. Pearl millet was shown to develop deep roots even when soil environment is not adequate in $\mathrm{pH}$ or penetration resistance (Fig. 2). This crop can extract large amounts of nitrate from soil at depths of $1.2 \mathrm{~m}$ in USA (Menezes et al., 1997) and $1.5 \mathrm{~m}$ in the Northern Territory of Australia (Wetselaar and Norman, 1960), while sorghum could only take up significant amounts of $\mathrm{N}$ to a depth of $0.6 \mathrm{~m}$. Even though the depth of pearl millet roots is not correlated with the rate of $\mathrm{N}$ applied, a greater proportion of deep roots have been found where no $\mathrm{N}$ was applied (Menezes et al., 1997). Therefore, $\mathrm{N}$ uptake from the subsoil is likely to be higher when no $\mathrm{N}$ is applied to pearl millet. 


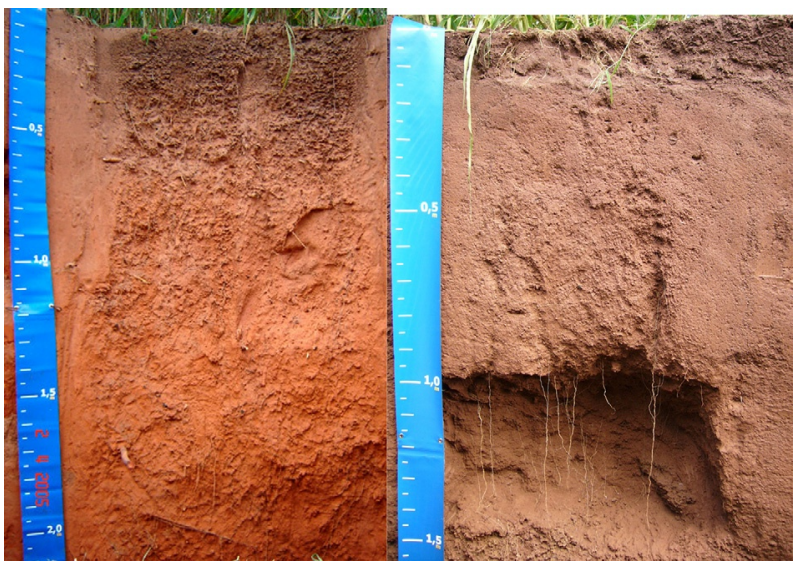

Fig. 2 Pearl millet fine roots growing below $2.0 \mathrm{~m}$ in the soil profile.

In an experiment using in the rotation combinations of deep and shallow-rooted crops ranging from $0.5 \mathrm{~m}$ (leek), to $\sim 1.0 \mathrm{~m}$ (ryegrass and barley), $1.5 \mathrm{~m}$ (red beet), $2.0 \mathrm{~m}$ (fodder radish and white cabbage), and more than $2.5 \mathrm{~m}$ by the chicory catch crop, Thorup-Kristensen (2006) found a significant retention of $\mathrm{N}_{\text {inorg }}$ within the $2.5 \mathrm{~m}$ soil profile from 1 year to the next, and the retention in the deeper soil layers allowed $N_{\text {inorg }}$ to be taken up by succeeding deep-rooted main or catch crops.

Crop-livestock integration systems are becoming increasingly popular in Brazil, and this may be an important practice to improve NUE in agriculture. Schröder et al. (1996) studied N recovery in maize under sown with grass, with rye used as cover crop after the grain crop. They concluded, after 6 years, that $115 \%$ of the aboveground $N$ from rye and $73 \%$ of the $N$ in the grass were recovered in the crop-soil system. Furthermore, by using modeling, Whitmore and Schröder (2007) reported that under-sowing grass between the rows of an established maize crop can reduce nitrate concentration in the drainage water during the winter when compared with a cover crop and with fallow soil. These studies suggest that yield and profitability of mixed stands is inversely related to the residual soil nitrate at harvest.

It has been reported also that the combined application of $\mathrm{N}$ and $P$ fertilizers stimulate maize root growth and branching throughout the soil profile, resulting in higher $\mathrm{N}$ uptake and greater maize grain yield, and consequently decreased soil $\mathrm{N}$ accumulation throughout the soil profile (Wen et al., 2016). According to these authors, these effects can be further enhanced with the application of manure, probably due to its role as a nutrient source and its effects improving soil structure. 
In addition to rooting depth, an efficient catch crop must have fast and early root growth and branching, which results in a rapid $\mathrm{N}$ depletion in the soil profile. Moreover, it is desirable that crops develop enough vegetative tissues in the canopy and be an efficient sink for $\mathrm{N}$, which will return to the soil as the straw is mineralized. Early uptake of $\mathrm{N}$ from the topsoil layers will decrease the downward movement of nitrate, thereby reducing nitrate present in deeper soil layers and decreasing leaching below the root zone. During drought spells, there is an upward movement of soil solution via capillary action, which allows catch crops to deplete soil $\mathrm{N}$ from even below the rooting zone. The introduction of grasses with a vigorous root growth in the cropping system will decrease $\mathrm{NO}_{3}{ }^{-}$concentrations in the soil solution, demonstrating its potential for incorporation into no-till soybean production systems. However, to decrease $\mathrm{N}$ leaching from cropping systems it is important to alternate $\mathrm{N}$-fixing species with plants with high $\mathrm{N}$ accumulation. The intensive use of fertility building crops such as green manures and catch crops strongly reduces $\mathrm{N}$ losses to the environment, because root exploitation of the soil volume is almost doubled (ThorupKristensen et al., 2012).

\section{N CYCLING IN CROPPING SYSTEMS}

When plant residues are not removed from the cropping system, the $\mathrm{N}$ released from these residues returns to the soil, and can be immobilized and then mineralized, leached, and lost or can be taken up by the next crop. Depending on their nature and the associated soil properties, plant residues modify inorganic $\mathrm{N}$ fate (Chen et al., 2014). Cover crops can increase mineral and organic $\mathrm{N}$ in the soil, which can be considered as credit for the next crop that may not respond to fertilizer $\mathrm{N}$. This could be an interesting way to enhance NUE in cropping systems, but the problem is that usually there is no synchronism between $\mathrm{N}$ release by the cover crop and the demand of the next crop. The $\mathrm{C} / \mathrm{N}$ ratio has been frequently used to estimate $\mathrm{N}$ fate in the system, but it has been shown that it is not always effective in predicting $\mathrm{N}$ mineralization of plant residues (Chen et al., 2014). Instead, soil properties and the forms of carbon and nitrogen should be considered (Chen et al., 2014). The amount of $\mathrm{N}$ mineralized was best correlated with the $\mathrm{C} / \mathrm{N}$ ratio of the plant residues, whereas the mineralization rate was well correlated with the lignin/ $\mathrm{N}$ ratio of the straw (Chaves et al., 2004). Plant residue mineralization almost always promotes $\mathrm{N}$ uptake by the next crop, but also 
increases the risk of $\mathrm{N}$ loss, depending on the synchronism between soil inorganic $\mathrm{N}$ changes and crop demand.

Chen et al. (2014) studying the decay of plant residues including vegetables, green manure, and leguminous crops concluded that mineralization occurs when $\mathrm{C} / \mathrm{N}$ ratios range from 9.4 to 22.7 . Immobilization followed by mineralization was observed in materials with $\mathrm{C} / \mathrm{N}$ rations from 30.3 to 136 , whereas $\mathrm{N}$ was immobilized when the residues had $\mathrm{C} / \mathrm{N}$ ratios from 46.5 to 99.4. Therefore, there is no clear line dividing immobilization-mineralization and immobilizations processes. These limits were obtained in different experimental periods, which can explain most of the variation. As the lignin/ $\mathrm{N}$ ratio is one the drivers of the mineralization rate, the time allowed for immobilization-mineralization will affect the experimental findings. The problem is that in agricultural systems with crop rotations where annual species residues are returned to the soil, the time for cover crop growth and $\mathrm{N}$ cycling is limited, sometimes leading to a net immobilization by the time the cash crop is planted. In crop-livestock integration systems, both grass roots in the soil and straw on the surface can temporarily immobilize nitrogen.

The cover crop used to produce the mulch necessary for no-till has a significant effect not only on yield but also on the fertilizer $N$ uptake of the main crop. Silva et al. (2006) compared a legume and a grass as cover crops for no-till maize grown on a highly weathered oxisol in Brazil, and found that the previous legume crop not only increased grain yield but also the $\mathrm{N}$ uptake from the fertilizer side dressed in the maize crop (Table 1). A recent meta-analysis by Qin et al. (2015) also indicated that soil mulching

Table 1 Effect of Previous Cover Crop on Yield and on N Fertilizer Use Efficiency of Maize Grown on a Red Latosol Soil Under No-Till

\section{Cover Crop}

\begin{tabular}{llllll}
\cline { 2 - 4 } Cover Crop & $\begin{array}{l}\text { Dry Mass } \\
(\mathbf{t ~ h a}\end{array}$ & $\begin{array}{l}\text { Accumulated } \\
\mathbf{N}\left(\mathbf{k g ~ h a}^{-1}\right)\end{array}$ & $\begin{array}{l}\text { Maize Grain } \\
\text { Yield }^{\mathrm{a}}\left(\mathbf{t ~ h a ~}^{-1}\right)\end{array}$ & $\begin{array}{l}\text { N Fertilizer Use } \\
\text { Efficiency }^{\mathrm{b}} \mathbf{( \% )}\end{array}$ \\
\hline Sunn hemp & 9.8 & 169 & $7.8^{\mathrm{a}}$ & $54^{\mathrm{a}}$ \\
\hline Millet & 7.4 & 69 & $5.9^{\mathrm{c}}$ & $44^{\mathrm{b}}$ \\
\hline Spontaneous vegetation & 2.5 & 28 & $6.4^{\mathrm{b}}$ & $51^{\mathrm{a}}$ \\
\hline
\end{tabular}

${ }^{\mathrm{a}}$ Yields are average of three $\mathrm{N}$ rates.

${ }^{\mathrm{b}} \mathrm{NUE}$ of aboveground parts based on ${ }^{15} \mathrm{~N}$-labeled fertilizer methods. $\mathrm{N}$ sidedressed at four or eight leaf stage.

${ }^{c}$ Different letters show significant differences (LSD, P $\left.<0.05\right)$.

Based on Silva et al. Silva, E.C., Muraoka, T., Buzetti, S., Trivelin, P.C.O., 2006. Manejo de nitrogênio no milho sob plantiodireto com diferentes plantas de cobertura, em Latossolo Vermelho. Pesq. Agrop. Bras. 41, 477-486. 
may increase NUE between $20 \%$ and $60 \%$ for crops such as maize and wheat. Despite the high amounts of $\mathrm{N}$ in the legume straw in the study of Silva et al. (2006) the maize crop still responded to $\mathrm{N}$ fertilization, although the fertilizer supplied only about $23 \%$ of the $\mathrm{N}$ accumulated in the plant. These figures are in line with the results reported by Dourado Neto et al. (2010) for studies conducted in 13 diverse tropical ecosystems in which soils were the primary source of $\mathrm{N}$ for plants.

Most of the annual crops take up less than $5 \%$ of their $\mathrm{N}$ at the seedling stage, between $70 \%-80 \%$ during the vegetative stage and $15 \%-25 \%$ during the reproductive stage. Usually the $\mathrm{N}$ uptake rate is at a maximum from 35-40 to 80-90 days after plant emergence. An $\mathrm{N}$ surplus early in the cycle will result in nitrate being transported down in the soil profile, as well as if the surplus is observed during the reproductive period. Conversely, if not enough $\mathrm{N}$ is available, mainly at the vegetative stage when the uptake rate is maximum, yield will be decreased. Chen et al. (2014) reviewed previous research where the incorporation of plant residues resulted in decreased yields of the next crop. However, plant residues were incorporated in the soil in most of those studies, and when they are left on the soil surface the mineralization/immobilization rate is different. Unfortunately, there is a shortage of literature concerning these situations.

Under no-till, the straw on the soil surface does not compete directly with the next crop for $\mathrm{N}$, but root residues may impose some harm by immobilizing $\mathrm{N}$. Cotton growth and $\mathrm{N}$ uptake were decreased when cropped in the presence of ruzigrass roots (Echer et al., 2012), and Rosolem et al. (2012), by separating cotton roots from ruzigrass roots using $\mathrm{C}$ isotope fractioning, found that ruzigrass roots had high $\mathrm{C} / \mathrm{N}$ ratios and had lost only $14 \%$ of its initial mass 45 days after termination, increasing soil $\mathrm{N}$ immobilization. The $\mathrm{N}$ returning from the straw on the soil surface was not enough to meet plant demand, which resulted in deficient cotton plants that required from 80 to $120 \mathrm{mg} \mathrm{kg}^{-1}$ of $\mathrm{N}$ to compensate for the immobilization. However, the use of plant residues with low $\mathrm{C} / \mathrm{N}$ ratios, as legumes, could enhance the synchronism, as shown by Kumar and Goh (2002) in wheat, although this is not always true. Maize yields, $\mathrm{N}$ uptake, and $\mathrm{N}$ derived from the fertilizer were increased after Sunn hemp as compared with pearl millet and fallow (Silva et al., 2006). As $\mathrm{N}$ derived from fertilizer was enhanced, the effect cannot be credited to Sunn hemp. In addition, most of the $\mathrm{N}(77 \%)$ in the plant was taken up from the soil and other sources. Maize cropped after black mucuna absorbed from $9.6 \%$ to $14.4 \%$ of the $\mathrm{N}$ left in the system by this cover crop, depending on the rate of mineral fertilization with urea (Scivittaro et al., 2000). Jensen (1994) found that 
$\mathrm{N}$ recovery from the previous cropped peas amounted to $13.0 \%, 3.0 \%$, and $1.5 \%$ in the first, second, and third years, respectively, and $41 \%-45 \%$ of the $\mathrm{N}$ was in an organic stable pool, or in the soil microbial mass. In Brazil, around $75 \%$ of the $\mathrm{N}$ derived from Sunn hemp was found in the soil because it had not been taken up by the wheat that followed Sunn hemp (Lange et al., 2009). Similar results had been obtained in the second year of wheat in Australia (Ladd et al., 1983). In Brazil, it has been shown that less than 7\% of the $\mathrm{N}$ applied to palisade grass was recovered in maize plants that followed grass desiccation, and there was no residual effect of the fertilizer applied to this grass (Borghi et al., 2014). Dourado Neto et al. (2010) reported that only 7\% of the $\mathrm{N}$ from plant residues were recovered by crops in the first season and about $9 \%$ in the subsequent seasons. Most of the $\mathrm{N}$ from plant residues ended up contributing to the pool of organic soil $\mathrm{N}$, which is slowly available, the fate of the fertilizer $\mathrm{N}$ not taken up by the crop was also the soil. Therefore, agricultural systems such as no-till associated with cover crops or systems in which the soil is cropped all year round with different species of plants, with diverse root sizes and architecture, offer an opportunity not only to decrease $\mathrm{N}$ losses but also to increase biomass yields.

The nitrate concentration in the soil solution in a soil covered with black oat, oil radish, and millet residues was not increased by the cover crops 36 days after maize emergence (Rosolem and Silva, 2010). At 47 days after maize emergence soil nitrate at the depth of $10 \mathrm{~cm}$ was not modified by cover crops, but at $30 \mathrm{~cm}$ there was less nitrate in solution with black oat and millet (Rosolem and Silva, 2010). Soil mineral $N$ was increased as $\mathrm{N}$ in plant residues declined up to 30 days after maize emergence (90 days after desiccation of the cover crops), and started decrease from 60 days after maize emergence. Interestingly, when $\mathrm{N}$ was applied to pearl millet and black oats, and the $\mathrm{C} / \mathrm{N}$ ratio was lower, soil $\mathrm{N}$ increased up to 60 days after corn emergence (Rosolem et al., 2004). Nitrogen fertilization increases dry matter and accumulation of $\mathrm{N}$ by palisade grass, decreasing the $\mathrm{C} / \mathrm{N}$ ratio, though cellulose and lignin contents are not affected, as well as residue decomposition and $\mathrm{N}$ release. The maximum $\mathrm{N}$ release rate from palisade grass is observed from 0 to 14 days (Fig. 3) after desiccation (Costa et al., 2016a). In black oats, most of the $\mathrm{N}$ in plant residues is released up to 34 days after desiccation and is faster than $\mathrm{C}$ mineralization (Crusciol et al., 2008). Nitrogen release rates are faster than $\mathrm{C}$ mineralization also in palisade grass (Fig. 3), Guinea grass, and pearl millet (Costa et al., 2016b). Hence, a lower $\mathrm{C} / \mathrm{N}$ does not guarantee an early $\mathrm{N}$ availability of the $\mathrm{N}$ washed from plant residues left on the soil surface. 

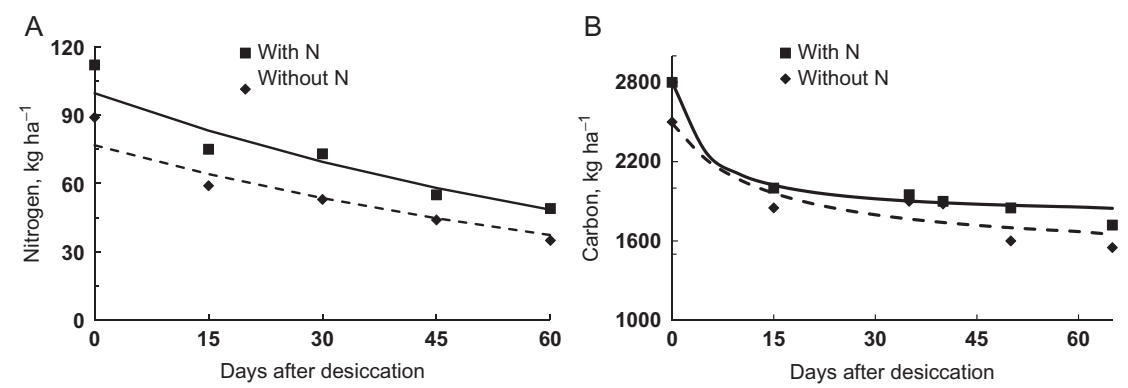

Fig. 3 Nitrogen and carbon remaining in the phytomass of palisade grass (Urochloa brizanta) after desiccation. From Costa, C.H.M., Crusciol, C.A.C., Soratto, R.P., Ferrari Neto, J., 2016. Phytomass decomposition and nutrients release from pearl millet, guinea grass and palisade grass. Biosci. J. 32, 1191-1203.

Part of the $\mathrm{N}$ contained in plants used as cover crops may also be lost in gaseous forms and desiccation with herbicides may enhance such losses. Damin et al. (2008) applied ${ }^{15} \mathrm{~N}$-labeled fertilizer to B. decumbens grown under controlled conditions and observed that $\mathrm{N}$ recovery in the plant-soil system was $66.5 \%$ but decreased to around $47 \%$ just 10 days after the grass was treated with glyphosate or glufosinate herbicides, probably due to $\mathrm{N}$ losses in the aboveground parts of the plant. Such losses deserve attention because desiccation of plants, including Brachiarias, to serve as mulch for no-till seeding is a common practice in Brazil.

The amount of $\mathrm{N}$ leached from $\mathrm{C} 4$ grass residues is lower than from residues of $\mathrm{C}_{3}$ species, which was attributed to a higher $\mathrm{C} / \mathrm{N}$ ratio and a stronger bound of $\mathrm{N}$ in organic compound in the $\mathrm{C}_{4}$ species (Rosolem et al., 2010). A higher $\mathrm{C} / \mathrm{N}$ ratio, if not affecting $\mathrm{N}$ release, is important in delaying plant residue mineralization on the soil surface, and is better than legumes and other low $\mathrm{C} / \mathrm{N}$ ratio species in protecting the soil and maintaining soil water. Therefore, grasses are important in a cropping system, and can be recommended in rotations in tropical areas, provided they receive nitrogen fertilizer and have no allelopathy (Rosolem et al., 2004).

Environmental concerns have led to call for a sustainable intensification of cropping systems with the introduction of legume-supported systems, to exploit biological nitrogen fixation (BNF), aiming to mitigate the inefficient NUE in current cropping systems in Europe (Hanson et al., 2007). An increased proportion of legume crops in a rotation was suggested as a means to decrease the amount of fertilizer $\mathrm{N}$ used and decrease reactive $\mathrm{N}$ losses from the system (Seufert et al., 2012), since BNF was shown to have the potential to generate benefits in reducing or dispensing the use of mineral 
$\mathrm{N}$ without yield loss (Ianetta et al., 2016). However, legume cover crops such as Sunn hemp grown in rotation with cash crops can eventually increase $\mathrm{NO}_{3}{ }^{-}$leaching, because it enriches the soil profile with the high $\mathrm{N}$ input by biological fixation. Conversely, millet resulted in the lowest $\mathrm{N}$ leaching by depleting the soil solution, and chiseling/fallow resulted in higher nitrogen leaching as compared with nonfixing $\mathrm{N}$ cover crops.

An important point is that, on average, maize yields increased after 6 years in rotation with cover crops, and $115 \%$ and $73 \%$ of aboveground rye and grass $\mathrm{N}$, respectively, can be recovered in the crop-soil system. Hence, the effects of cover crops accumulate when grown repeatedly (Schröder et al., 1996). Grain yields and leaf macronutrient concentrations were higher in soybean, white oat, and corn in previously intercropped areas than in monocropped areas (Schröder et al., 1996). Hence, the incorporation of a perennial forage grass in the rotation as a cover crop will improve soil fertility and increase grain yields of agricultural cropping systems (Crusciol et al., 2015). Therefore, while the nitrogen from crops and cover crops grown previously is not available immediately, it constitutes an important soil reserve, acting akin to a slow-release fertilizer.

\section{KEY RESEARCH CHALLENGES}

It has been well established that an ideal plant species to conserve $\mathrm{N}$ in the agricultural system must have a vigorous, deep rooting system, as well as an early and vigorous shoot growth, capable of accumulating large amounts of N. It is important to introduce species with different rooting patterns in a cropping system to better explore $\mathrm{N}$ in the soil profile; hence, mixed crop stands would be a very attractive approach, though there is currently a significant knowledge gap on their effectiveness. Species diversity in a cropping system offers much potential, but there is much yet to be explored.

The use of legumes in a cropping system is an important way to add $\mathrm{N}$ without using mineral fertilizers; however, the danger of $\mathrm{N}$ leaching is not offset, because as legumes enrich the subsoil, leaching can be increased. Therefore, a companion plant with deep, large root systems is important in these cases. For each environment, there will be an appropriate species combination.

Another significant research gap concerns the fate of the $\mathrm{N}$ released from plant residues in the soil, because usually it is not found as nitrate in the soil profile, and very little is used by the next crop. $\mathrm{N}$ cycling is important in improving NUE, but the results are more expressive in the long term. 
Therefore, it seems important to increase the amount of $\mathrm{N}$ in soil-plant system, which will depend on increasing soil $\mathrm{C}$ to avoid losses.

The potential to harness plant: microbe interactions with respect to close mutualism through to more general interactions are also enormous. While many of the basic principles are now understood, the precise mechanisms, and means to deal with the inherent complexity arising from the meeting of extreme microbial diversity belowground with relative botanical simplicity in cropping systems are still largely elusive.

\section{ACKNOWLEDGMENTS}

This work was undertaken as part of NUCLEUS: a virtual joint center to deliver enhanced NUE via an integrated soil-plant systems approach for the United Kingdom and Brazil. Funded in by Brazil by FAPESP-São Paulo Research Foundation (Grant 2015/50305-8), FAPEG-Goias Research Foundation (Grant 2015-10267001479), and FAPEMA-Maranhão Research Foundation (Grant RCUK-02771/16); and in the United Kingdom by BBRSC/Newton Fund (BB/N013201/1). C.A.R. and H.C. hold Scholaships from CNPq (Brazilian National Council for Science and Technology Development); S.J.M. is funded by the ERC Future Roots project; M.J.H. and W.R.W. at Rothamsted Research are supported via the 20:20 Wheat ${ }^{\mathbb{R}}$ Programme by the UK Biotechnology and Biological Sciences Research Council.

\section{REFERENCES}

Abalos, D., Jeffery, S., Sanz-Cobena, A., Guardia, G., Vallejo, A., 2014. Meta-analysis of the effect of urease and nitrification inhibitors on crop productivity and nitrogen use efficiency. Agric. Ecosyst. Environ. 189, 136-144.

Adewopo, J.B., Vanzomeren, C., Bhomia, R.K., Almarz, M., Bacon, A.R., Eggleston, E., Judy, J.D., Lewies, R.W., Lusk, M., Miller, B., Moorber, C., Snyder, E.H., Tiedeman, M., 2014. Top ranked priority research questions for soil science in the 21st century. Soil Sci. Soc. Am. J. 78, 337-347.

Austin, A.T., Bustamante, M.C., Nardoto, G.B., Mitre, S.K., Perez, T., Ometto, J.P.J.B., Ascarrunz, N.L., Forti, M.S., Longo, K., Gavito, M.E., Enrich-Prast, A., Martinelli, L.A., 2013. Latin Americas's nitrogen challenge. Science 340, 149.

Avis, T.J., Gravel, V., Antoun, H., Tweddell, R.J., 2008. Multifaceted beneficial effects of rhizosphere microorganisms on plant health and productivity. Soil Biol. Biochem. 40, 1733-1740.

Baldani, J.I., Baldani, V.L.D., 2005. History on the biological nitrogen fixation research in graminaceous plants, special emphasis on the Brazilian experience. An. Acad. Bras. Ciênc. 77, 549-579.

Bao, Y., Aggarwal, P., Robbins, N.E., Sturrock, C.J., Thompson, M.C., Tan, H.Q., Tham, C., Duan, L., Rodriguez, P.L., Vernoux, T., Mooney, S.J., Bennett, M.J., Dinneny, J.R., 2014. Plant roots use a patterning mechanism to position lateral root branches toward available water. Proc. Natl. Acad. Sci. U. S. A. 111, 9319-9324.

Barber, S.A., Cushman, J.H., 1981. Nitrogen uptake model for agronomic crops. In: Iskandar, I.K. (Ed.), Modeling Wastewater Renovation-Land Treatment. WileyInterscience, New York, pp. 382-409. 
Billen, G., Garnier, J., Lassaletta, L., 2013. The nitrogen cascade from agricultural soils to the sea: modelling nitrogen transfers at regional watershed and global scales. Philos. Trans. R. Soc. B Biol. Sci. 368.

Bishnoi, U., 2015. PGPR interaction, an ecofriendly approach promoting the sustainable agriculture system. Plant Microb. Interact. 75, 81-113.

Boddey, R.M., Jantalia, C.P., Conceição, P.C., Zanatta, J.A., Bayer, C., Mielnizuk, J., Dieckow, J., Santos, H.P., Denardin, J.E., Aita, C., Giacomini, S.J., Alves, B.J.R., Urquiaga, S., 2010. Carbon accumulation at depth in Ferralsols under zero till subtropical agriculture. Glob. Chang. Biol. 16, 784-795.

Bonkowski, M., Villenave, C., Griffiths, B., 2009. Rhizosphere fauna, the functional and structural diversity of intimate interactions of soil fauna with plant roots. Plant Soil $321,213-233$.

Borghi, E., Crusciol, C.A.C., Trivelin, P.C.O., Nascente, A.S., Costa, C., Mateus, G.P., 2014. Nitrogen fertilization $\left(\left(\mathrm{NH}_{4} \mathrm{NO}_{3}\right)-{ }^{15} \mathrm{~N}\right)$ of palisade grass and residual effect on subsequent no-tillage corn. Rev. Bras. Ciênc. Solo 38, 1457-1468.

Bortolotto, R.P., Bruno, I.P., Reichardt, K., Timm, L.C., Amado, T.J.C., Ferreira, A.d.O., 2012. Nitrogen fertilizer $(15 N)$ leaching in a central pivot fertigated coffee crop. Rev. Ceres 49, 466-475.

Bouwman, A.F., Boumans, L.J.M., Batjes, N.H., 2002. Estimation of global $\mathrm{NH} 3$ volatilization loss from synthetic fertilizers and animal manure applied to arable lands and grasslands. Global Biogeochem. Cycles 16, 8-1-8-14. http://dx.doi.org/ 10.1029/2000GB001389.

Bremner, J.M., 1995. Recent research on problems in the use of urea as a nitrogen fertilizer. Fertil. Res. 42, 321-329.

Brown, P.D., Morra, M.J., 2009. Brassicacaeae tissues as inhibitors of nitrification in soil. J. Agric. Food Chem. 57, 7706-7711.

Cameron, K.C., Di, H.J., Moir, J.L., 2013. Nitrogen losses from the soil/plant system: a review. Ann. Appl. Biol. 162, 145-173.

Cantarella, H., 2007. Nitrogênio. In: Novaes, R.F., Hugo, A.V., Barros, F., Cantarutti, R.B., Neves, J.C.L. (Eds.), Fertilidade do Solo. Sociedade Brasileira de Ciência do Solo, Viçosa, pp. 375-470.

Cantarella, H., Mattos, D., Quaggio, J.A., Rigolin, A.T., 2003. Fruit yield of Valencia sweet orange fertilized with different $\mathrm{N}$ sources and the loss of applied N. Nutr. Cycl. Agroecosyst. 67, 215-223.

Cantarella, H., Trivelin, P.C.O., Contin, T.L.M., Dias, F.L.F., Rossetto, R., Marcelino, R., Coimbra, R.B., Quaggio, J.A., 2008. Ammonia volatilization from urease inhibitortreated urea applied to sugarcane trash blankets. Sci. Agric. 65, 397-401.

Carvalho, T.L.G., Balsemao-Pires, E., Saraiva, R.M., Ferreira, P.C.G., Hemerly, A.S., 2014. Nitrogen signalling in plant interactions with associative and endophytic diazotrophic bacteria. J. Exp. Bot. 65, 5631-5642.

Castoldi, G., Pivetta, L.A., Rosolem, C.A., 2014. Nitrogen budget in a soil-plant system after brachiaria grass desiccation. Soil Sci. Plant Nutr. 60, 162-172.

Castoldi, G., Reis, J.G., Pivetta, L.A., Rosolem, C.A., 2013. Soil nitrogen dynamics after brachiaria desiccation. Rev. Bras. Cienc. Solo 37, 1620-1627.

Castro, G.S.A., Crusciol, C.A.C., Calonego, J.C., Rosolem, C.A., 2015. Management impacts on soil organic matter of tropical soils. Vadose Zone J. 14, 1-8.

Chapman, N., Whalley, W.R., Lindsey, K., Miller, A.J., 2011. Water supply and not nitrate concentration determines primary, but not secondary root growth in Arabidopsis. Plant Cell Environ. 34, 1630-1638.

Chaves, B., De Neve, S., Hofman, G., Boeckx, P., Clemput, O.V., 2004. Nitrogen mineralization of vegetable root residues and green manures as related to their (bio) chemical composition. Eur. J. Agron. 21, 161-170. 
Chen, B., Liu, E., Tian, Q., Yan, C., Zhang, Y., 2014. Soil nitrogen dynamics and crop residues. A review. Agron. Sustain. Dev. 34, 429-442.

Chien, S.H., Prochnow, L.I., Cantarella, H., 2009. Recent developments of fertilizer production and use to improve nutrient efficiency and minimize environmental impacts. Adv. Agron. 102, 267-322.

Costa, C.H.M., Crusciol, C.A.C., Soratto, R.P., Ferrari Neto, J., 2016a. Phytomass decomposition and nutrients release from pearl millet, guinea grass and palisade grass. Biosci. J. 32, 1191-1203.

Costa, C.H.M., Crusciol, C.A.C., Soratto, R.P., Ferrari Neto, J., Moro, E., 2016b. Nitrogen fertilization on palisadegrass: phytomass decomposition and nutrient release. Pesq. Agropec. Trop. 46, 159-168.

Costa, A., Rosolem, C.A., 2007. Liming in the transition to no-till under a wheat-soybean rotation. Soil Tillage Res. 97, 207-217.

Crusciol, C.A.C., Moro, E., Lima, E.V., Andreotti, M., 2008. Decomposition rate and nutrient release of oat straw used as mulching in no-till system. Bragantia 67, 481-489.

Crusciol, C.A.C., Nascente, A.S., Borghi, E., Soratto, R.P., Martins, P.O., 2015. Improving soil fertility and crop yield in a tropical region with palisade grass cover crop. Agron. J. 107, 2271-2280.

Cullimore, J.V., Ranjeva, R., Bono, J.J., 2001. Perception of lipo-chitooligosaccharidic nod factors in legumes. Trends Plant Sci. 6, 24-30.

Cunha, J.F., Casarin, V., Prochnow, L.I., 2011. Balanço de nutrientes n aagricultura brasileira de 1988 a 2010. Informações Agronômicas 135, 1-7.

Damin, V., Franco, H.C.J., Moraes, M.F., Franco, A., Trivelin, P.C.O., 2008. Perdas de nitrogênio por Brachiaria decumbens após a aplicação de glifosato ou glufosinato de amônio. Sci. Agric. 65, 402-407.

Damin, V., Trivelin, P.C.O., Carvalho, S.J.P., Moraes, M.F., Barbosa, T.G., 2010. Herbicide application increases nitrogen $\left({ }^{15} \mathrm{~N}\right)$ exudation and root detachment of Brachiaria decumbens Stapf. Plant Soil 334, 511-519.

Dobbelaere, S., Croonenborghs, A., Thys, A., VandeBroek, A., Vanderleyden, J., 1999. Phytostimulatory effect of Azospirillum brasilense wild type and mutant strains altered in IAA production on wheat. Plant Soil 212, 155-164.

Dobermann, A., 2007. Nutrient use efficiency-measurement and management. In: IFA (Ed.), General Principles of FBMPs. IFA International Workshop on Fertilizer Best Management Practices. IFA - Intl. Fertilizer Industry Association, BrusseIs, pp. 1-30. Part 1.

Dourado Neto, D., Powlson, D.S., Bakar, R., Bacchi, O.O.S., Basanta, M.V., Cong, P.T., Keerthisinghe, G., Ismaili, M., Rahman, S.M., Reichardt, K., Safwat, M.S.A., Sangakkara, R., Timm, L.C., Wang, J.Y., 2010. Multiseason recoveries or organic and inorganic nitrogen-15 in tropical cropping systems. Soil Sci. Soc. Am. J. 74, 139-152.

Drew, M.C., Saker, L.R., Ashley, T.W., 1973. Nutrient supply and growth of seminal root system in barley. 1. Effect of nitrate concentration on growth of axes and laterals. J. Exp. Bot. 24, 1189-1202.

Echer, F.R., Castro, G.S.A., Bogiani, J.C., Rosolem, C.A., 2012. Crescimento inicial e absorção de nutrientes pelo algodoeiro cultivado sobre palha de Brachiaria ruziziensis. Planta Daninha 30, 783-790.

Elmerich, C., Newton, W.E., 2007. Associative and Endophytic Nitrogen-Fixing Bacteria and Cyanobacterial Associations. Springer, Dordrecht, Netherlands.

Ernst, J.W., Massey, H.F., 1960. The effects of several factors on volatilization of ammonia formed from urea in the soil. Soil Sci. Soc. Am. J. 24, 87-90.

Fan, J., McConkey, B., Wang, H., Janzen, H., 2016. Root distribution for temperate agricultural crops. Field Crop Res. 189, 68-74. 
FAO, 2009. Global agriculture towards 2050. In: How to Feed the World 2050-High-Level Expert Forums. FAO-Food and Agriculture Organization, Rome, p. 4. www.fao.org/ fileadmin/templates/wsfs/docs/Issues_papers/HLEF2050_Global_Agriculture.pdf.

Faure, D., Vereecke, D., Leveau, J.H.J., 2009. Molecular communication in the rhizosphere. Plant Soil 321, 279-303.

Fernandes, A.M., Andrade, G.J.M., Souza, E.F.C., Rosolem, C.A., 2011. Brachiaria species affecting soil nitrification. Rev. Bras. Ciênc. Solo 35, 1699-1706.

Fernandes, F.C.S., Libardi, P.L., Carvalho, L.A., 2006. Internal drainage and nitrate leaching in corn-black oat corn succession with two split nitrogen applications. Sci. Agric. 63, 483-492.

Fixen, P., Brentup, F., Bruulsema, T., Garcia, F., Norton, R., Zingore, S., 2014. Nutrient/ fertilizer use efficiency: measurement, current situation and trends. In: Managing Water and Fertilizer for Sustainable Agricultural Intensification. IFA, IWMI, IPNI and IPI, ISBN: 979-10-92366-02-0.

Frame, W., 2017. Ammonia volatilization from urea treated with NBPT and two nitrification inhibitors. Agron. J. 109, 378-387.

Gao, W., Hodgkinson, L., Jin, K., Watts, C.W., Ashton, R.W., Shen, J., Ren, T., Dodd, I.C., Binley, A., Phillips, A.L., Hedden, P., Hawkesford, M.J., Whalley, W.R., 2016. Deep roots and soil structure. Plant Cell Environ. 39, 1662-1668.

Ghiberto, P.J., Libardi, P.L., Brito, A.S., Trivelin, P.C.O., 2009. Leaching of nutrients from a sugarcane crop growing on an Ultisol in Brazil. Agric. Water Manag. 96, 1443-1448.

Ghiberto, P.J., Libardi, P.L., Trivelin, P.C.O., 2015. Nutrient leaching in an Ultisol cultivated with sugarcane. Agric. Water Manag. 148, 141-149.

Gilsanz, C., Báez, D., Misselbrook, T.H., Dhanoa, M.S., Cárdenas, L.M., 2016. Development of emission factors and efficiency of two nitrification inhibitors, DCD and DMPP. Agric. Ecosyst. Environ. 216, 1-8.

Grindlay, D.J.C., 1995. Rooting depth in cover crops and its relation to shoot size. Principles governing the ability of cover crop species to trap nitrate. University of Nottingham, pp. 230-278. PhD thesis.

Haichar, F.E., Roncato, M.A., Achouak, W., 2012. Stable isotope probing of bacterial community structure and gene expression in the rhizosphere of Arabidopsis thaliana. FEMS Microbiol. Ecol. 81, 291-302.

Haichar, F.E., Santaella, C., Heulin, T., Achouak, W., 2014. Root exudates mediated interactions belowground. Soil Biol. Biochem. 77, 69-80.

Hanson, D., Liebig, M.A., Merrill, S.D., Tanaka, D.L., Krupinsky, M., Stott, D.E., 2007. Dynamic cropping systems: increasing adaptability amid an uncertain future. Agron. J. 99, 939-943.

Heffer, P., Prud'homme, M., 2013. Fertilizer Outlook 2013-2017. IFA-International Fertilizer Industry Association, Paris.

Hodge, A., 2004. The plastic plant: root responses to heterogeneous supplies of nutrients. New Phytol. 162, 9-24.

Hofstra, N., Bouwman, A.F., 2005. Denitrification in agricultural soils: summarizing published data and estimating global annual rates. Nutr. Cycl. Agroecosyst. 72, 267-278.

Holcomb, J.C., Sullivan, D.M., Horneck, D.A., Clough, G.H., 2011. Effect of irrigation rate on ammonia volatilization. Soil Sci. Soc. Am. J. 75, 2341-2347.

Hungria, M., Nogueira, M.A., Araujo, R.S., 2016. Inoculation of Brachiaria spp. with the plant growth-promoting bacterium Azospirillum brasilense, an environment-friendly component in the reclamation of degraded pastures in the tropics. Agric. Ecosyst. Environ. 221, 125-131.

Ianetta, P.M., Young, M., Bachinger, J., Bergkvist, G., Doltra, J., Lopez-Bellido, R.J., Monti, M., Pappa, V.A., Reckling, M., Topp, C.F.E., Walker, R.L., Rees, R.M., Watson, C.A., James, E.K., 2016. Legume supported cropping systems: the potential role 
of biological nitrogen fixation. Front. Plant Sci. http://dx.doi.org/10.3389/ fpls.2016.01700.

Ishikawa, T., Subbarao, G.V., Ito, O., Okada, K., 2003. Suppression of nitrification and nitrous oxide emission by the tropical grass Brachiaria humidicola. Plant Soil 255, 413-419.

Jensen, E.S., 1994. Availability of nitrogen in 15N-labelled mature pea residues to subsequent crops in the field. Soil Biol. Biochem. 26, 465-472.

Jones, D.L., Hodge, A., Kuzyakov, Y., 2004. Plant and mycorrhizal regulation of rhizodeposition. New Phytol. 163, 459-480.

Jones, D.L., Nguyen, C., Finlay, R.D., 2009. Carbon flow in the rhizosphere, carbon trading at the soil-root interface. Plant Soil 321, 5-33.

Kim, D.-G., Saggar, S., Roudier, P., 2012. The effect of nitrification inhibitors on soil ammonia emissions in nitrogen managed soils: a meta-analysis. Nutr. Cycl. Agroecosyst. 93, 51-64.

Kölln, O.T., Franco, H.C., Ferreira, D.A., Vargas, V.P., Castro, S.A.Q., Cantarella, H., Caldana, C., Trivelin, P.C.O., 2016. Root extract of Bracchiaria humidicola and Saccharum spontaneum to increase $\mathrm{N}$ use by sugarcane. Sci. Agric. 73, 34-42.

Kuijken, R.C.P., Snel, J.F.H., Heddes, M.M., Bouwmeester, H.J., Marcelis, L.F.M., 2015. The importance of a sterile rhizosphere when phenotyping for root exudation. Plant Soil 387, 131-142.

Kumar, K., Goh, K.M., 2002. Management practices of antecedent leguminous and nonleguminous crop residues in relation to winter wheat yields, nitrogen uptake, soil nitrogen mineralization and simple nitrogen balance. Eur. J. Agron. 16, 295-308.

Kutschera, L., Lichtenegger, E., 1982. WurzelatlasmitteleuropäischerGrünlandpflanzen. Band I. Monocotyledoneae. Gustav Fischer Verlag, Stuttgart, New York.

Kuzyakov, Y., 2010. Priming effects, interactions between living and dead organic matter. Soil Biol. Biochem. 42, 1363-1371.

Ladd, J.N., Amato, M., Jackson, R.B., Butler, J.H.A., 1983. Utilization by wheat crops of nitrogen from legume residues decomposing in soils in the field. Soil Biol. Biochem. $15,231-238$.

Lange, A., Bologna, I.R., Faroni, C.E., Trivelin, P.C.O., 2009. Recovery by wheat of residual nitrogen from crotalária (Crotalaria juncea) and urea of previous crop soil fertilization. Ciênc. Rural 36, 1715-1720.

Lara Cabezas, W.A.R., Alves, B.J.R., Urquiaga, S., Santana, D.G., 2004. Influência da cultura antecessora e da adubação nitrogenada na produtividade de milho em sistema plantio direto e solo preparado. Cienc. Rural 34, 1005-1013.

Lara Cabezas, W.A.R., Souza, M.A., 2008. Volatilização de amônia, lixiviação de nitrogênio e produtividade de milhoemresposta à aplicação de misturas de ureia com sulfato de amônioou com gesso agrícola. Rev. Bras. Cienc. Solo 32, 2331-2342.

Li, Q., Yang, A., Wang, Z., Roelcke, M., Chen, X., Zhang, F.-S., Pasda, G., Zerulla, W., Wissemeier, A.H., Liu, X., 2015. Effect of a new urease inhibitor on ammonia volatilization and nitrogen utilization in wheat in north and northwest China. Field Crop Res. 175, 96-105.

Linquist, B.A., Liu, L., van Kessel, C., van Groenigen, K.J., 2013. Enhanced efficiency nitrogen fertilizers for rice systems: meta-analysis of yield and nitrogen uptake. Field Crop Res. 154, 246-254.

Liu, C., Wang, K., Zheng, X., 2013. Effects of nitrification inhibitors (DCD and DMPP) on nitrous oxide emission, crop yield and nitrogen uptake in a wheat-maize cropping system. Biogeosciences 10, 2427-2437.

Lopes, A.S., Guilherme, L.R.G., 2016. A career perspective on soil management in the cerrado region of Brazil. Adv. Agron. 137, 1-72.

Lucy, M., Reed, E., Glick, B.R., 2004. Applications of free living plant growth-promoting rhizobacteria. Antonie Van Leeuwenhoek 86, 1-25. 
Lyu, Y., Tang, H., Li, H., Zhang, F., Rengel, Z., Whalley, W.R., Shen, J., 2016. Major crop species show differential balance between root morphological and physiological responses to enhance phosphorus acquisition. Front. Plant Sci. 7, 1939. http://dx.doi. org/10.3389/fpls.2016.019.

Mangalassery, S., Sjögersten, S., Sparkes, D.L., Sturrock, C.J., Craigon, J., Mooney, S.J., 2014. To what extent can zero tillage lead to a reduction in greenhouse gas emissions from temperate soils? Sci. Rep. 4, 4586.

Marstorp, H., 1995. Influence of protein degradation and protein content in cut Lolium multiflorum leaves on the delay in ammonia volatilization. Swed. J. Agric. Res. 25, 179-183.

Meier, I.C., Finzi, A.C., Phillips, R.P., 2017. Root exudates increase N availability by stimulating microbial turnover of fast-cycling N pools. Soil Biol. Biochem. 106, 119-128.

Menezes, R.S.C., Gasho, G.J., Hanna, W.W., Cabrera, M.L., Hook, J.E., 1997. Subsoil nitrate uptake by grain pearl millet. Agron. J. 89, 189-194.

Mkhabela, M.S., Madani, A., Gordon, R., Burton, D., Cudmore, D., Elmi, A., Hart, W., 2008. Gaseous and leaching nitrogen losses from no-tillage and conventional tillage systems following surface application of cattle manure. Soil Tillage Res. 98, 187-199.

Müller, C., Laughlin, R.J., Spott, O., Rütting, T., 2014. Quantification of N2O emission pathways via a $15 \mathrm{~N}$ tracing model. Soil Biol. Biochem. 72, 44-54.

Murphy, C.J., Baggs, E.M., Morley, N., Wall, D.P., Patersons, E., 2015. Rhizosphere priming can promote mobilisation of $\mathrm{N}$-rich compounds from soil organic matter. Soil Biol. Biochem. 81, 236-243.

Norton, R., Davidson, E., Roberts, T., 2015. Nitrogen Use Efficiency and Nutrient Performance Indicators. Global Partnership on Nutrient Management, Washington15 pp..

Ober, E.S., Werner, P., Flatman, E., Angus, W.J., Jack, P., Smith-Reeve, L., Tapsell, C., 2014. Genotypic differences in deep water extraction associated with drought tolerance in wheat. Funct. Plant Biol. 41, 1078-1086.

Oenema, O., Brentrup, F., Lammel, J., Bascou, P., Billen, G., Dobermann, A., Erisman, J.W., Garnett, T., Hammel, M., Haniotis, T., Hillier, J., Hoxha, A., Jensen, L.S., Oleszek, W., Pallière, C., Powlson, D.S., Quemada, M., Schulman, M., Sutton, M.A., van Grinsven, H.J.M., Winiwarter, W., 2015. EU Nitrogen Expert Panel-Nitrogen Use Efficiency (NUE) - An Indicator for the Utilization of Nitrogen in Agriculture and Food Systems. Wageningen University, Alterra.

Oenema, O., Ju, X., de Klein, C., Alfaro, M., del Prado, A., Lesschen, J.P., Zheng, X., Velthof, G., Ma, L., Gao, B., Kroeze, C., Sutton, M., 2014. Reducing nitrous oxide emissions from the global food system. Curr. Opin. Environ. Sustain. 9-10, 55-64.

Okon, Y., Labanderagonzalez, C.A., 1994. Agronomic applications of Azospirillum - an evaluation of 20 years worldwide field inoculation. Soil Biol. Biochem. 26, 1591-1601.

Paul, E.A., Clark, F.E., 1989. Reduction and transport of nitrate. In: Paul, E.A., Clark, F.E. (Eds.), Soil Microbiology and Biochemistry. Academic Press, New York, pp. 147-162.

Pires, M.V., Cunha, D.A., Carlos, S.M., Costa, M.H., 2015. Nitrogen-use efficiency, nitrous oxide emissions, and cereal production in Brazil: current trends and forecasts. PLoS One 10, e0135234. http://dx.doi.org/10.1371/journal.pone0135234.

Qin, W., Hu, C., Oenema, O., 2015. Soil mulching significantly enhances yields and water and nitrogen use efficiencies of maize and wheat: a meta-analysis. Sci. Rep. 5, 16210. http://dx.doi.org/10.1038/srep16210.

Quaggio, J.A., Ramos, V.J., Furlani, P.R., Carelli, M.L.C., 1991. Liming and molybdenum effects on nitrogen uptake and grain yield of corn. In: Wright, R.J. (Ed.), Plant-Soil Interactions at Low pH. Kluwer Academic Publishers, Dordrecht, pp. 953-958.

Quaggio, J.A., Sakai, J., Ishimura, I., Saes, L.A., Bataglia, O.C., 1985. Liming for the beansmaize rotation in an organic soil of Ribeira de Iguapé River basin. Rev. Bras. Ciênc. Solo $2,225-261$. 
Raaijmakers, J.M., Paulitz, T.C., Steinberg, C., Alabouvette, C., Moenne-Loccoz, Y., 2009. The rhizosphere, a playground and battlefield for soil borne pathogens and beneficial microorganisms. Plant Soil 321, 341-361.

Raun, W.R., Johnson, G.V., 1999. Improving nitrogen use efficiency for cereal production. Agron. J. 91, 357-363.

Reetz Jr., H.F., 2016. Fertilizers and their Efficient Use. IFA-International Fertilizer Industry Association, Paris.

Rekha, P.N., Kanwar, R.S., Nayak, A.K., Hoang, C.K., Pederson, C.H., 2011. Nitrate leaching to shallow groundwater systems from agricultural fields with different management practices. J. Environ. Monit. 13, 2550-2558.

Ritchey, K.D., Feldhake, C.M., Clark, R.B., Sousa, D.M.G., 1995. Improved water and nutrient uptake from subsurface layers of gypsum-amended soils. In: Karlen, D.L.R., Wright, J., Kemper, W.O. (Eds.), Agricultural Utilization of Urban and Industrial By-Products. American Society of Agronomy, Crop Science Society of America, Soil Science Society of America, Madison, WI, pp. 157-181.

Robinson, D., 1986. Limits to nutrient inflow rates in roots and root systems. Physiol. Plant. 68, 551-559.

Rochette, P., Angers, D.A., Chantigny, M.H., Gasser, M.O., MacDonald, J.D., Pelster, D.E., Bertrand, N., 2013. Ammonia volatilization and nitrogen retention: how deep to incorporate urea? J. Environ. Qual. 42, 1635-1642.

Rosolem, C.A., Li, Y., Garcia, R.A., 2016. Soil carbon as affected by cover crops under no-till under tropical climate. Soil Use Manag. 32, 495-503.

Rosolem, C.A., Pace, L., Crusciol, C.A.C., 2004. Nitrogen management in maize cover crop rotations. Plant Soil 264, 261-271.

Rosolem, C.A., Silva, R.H., 2010. Soil solution as affected by plant residues and nitrogen rates. Commun. Soil Sci. Plant Anal. 41, 13-28.

Rosolem, C.A., Steiner, F., Zoca, S.M., Ducatti, C., 2012. Nitrogen immobilization by Congo grass roots impairs cotton initial growth. J. Agric. Sci. 4, 126-136.

Rosolem, C.A., Werle, R., Garcia, R.A., 2010. Nitrogen washing from C3 and C4 cover grasses residues by rain. Rev. Bras. Cienc. Solo 34, 1899-1905.

Sapkota, T.B., Askegaard, M., Lægdsmand, M., Olesen, J.E., 2012. Effects of catch crop type and root depth on nitrogen leaching and yield of spring barley. Field Crop Res. 125, 129-138.

Schröder, J.J., Dijk, W., Groot, W.J.M., 1996. Effect of cover crops on the nitrogen fluxes in a silage maize production system. Neth. J. Agric. Sci. 44, 293-315.

Scivittaro, W.B., Muraoka, T., Boaretto, A.E., Trivelin, P.C.O., 2000. Utilização de nitrogênio de adubos verde e mineral pelo milho. Rev. Bras. Ciênc. Solo 24, 917-926.

Seufert, V., Ramankutty, N., Foley, J.A., 2012. Comparing the yields of organic and conventional agriculture. Nature 485, 229-232.

Shinano, T., Osaki, M., Yamada, S., Tadano, T., 1994. Comparison of root growth and nitrogen absorbing ability between Gramineae and Leguminosae during the vegetative stage. Soil Sci. Plant Nutr. 40, 485-495.

Silva, E.C., Muraoka, T., Buzetti, S., Trivelin, P.C.O., 2006. Manejo de nitrogênio no milho sob plantiodireto com diferentes plantas de cobertura, em Latossolo Vermelho. Pesq. Agropec. Bras. 41, 477-486.

Silva, R.H., Rosolem, C.A., 2003. Early development and nutrition of cover crop species as affected by soil compaction. J. Plant Nutr. 26, 1636-1648.

Silva, A.G.B., Sequeira, C.H., Sermarini, R.A., Otto, R., 2017. Urease inhibitor NBPT on ammonia volatilization and crop productivity: a meta-analysis. Agron. J. 109, 1-13. 
Snyder, C.S., Bruulsema, T.W., Jensen, T.L., Fixen, P.E., 2009. Review of greenhouse gas emissions from crop production systems and fertilizer management effects. Agric. Ecosyst. Environ. 133, 247-266.

Snyder, C.S., Davidson, E.A., Smith, P., Venterea, R.T., 2014. Agriculture: sustainable crop and animal production to help mitigate nitrous oxide emissions. Curr. Opin. Environ. Sustain. 9-10, 46-54.

Soares, J.R., Cantarella, H., Menegale, M.L.C., 2012. Ammonia volatilization losses from surface-applied urea with urease and nitrifications inhibitors. Soil Biol. Biochem. 52, 82-89.

Soares, J.R., Cantarella, H., Vargas, V.P., Carmo, J.B., Martins, A.A., Sousa, R.M., Andrade, C.A., 2015. Enhanced-efficiency fertilizers in nitrous oxide emissions from urea applied to sugarcane. J. Environ. Qual. 44, 423-430.

Soares, J.R., Cassman, N.A., Kielak, A.M., Pijl, A., Carmo, J.B., Lourenço, K.S., Laanbroek, H.J., Cantarella, H., Kuramae, E.E., 2016. Nitrous oxide emission related to ammonia-oxidizing bacteria and mitigation options from $\mathrm{N}$ fertilization in a tropical soil. Sci. Rep. 6, 30349.

Spaepen, S., Vanderleyden, J., Okon, Y., 2009. Plant growth-promoting actions of rhizobacteria. Plant. Innate Immun. 51, 283-320.

Subbarao, G.V., Ito, O., Sahrawat, K.L., Berry, W.L., Nakahara, K., Ishiwawa, T., Watanabe, T., Suenaga, K., Rondon, M., Rao, I.M., 2006. Scope and strategies for regulation of nitrification in agricultural systems - challanges and opportunities. Crit. Rev. Plant Sci. 25, 303-335.

Subbarao, G.V., Nakahara, K., Hurtado, M.P., Ono, H., Moreta, D.E., Salcedo, A.F., Yoshihashi, A.T., Ishiwawa, T., Ishitani, M., Ohnishi-Kameyama, M., Yoshida, M., Rondon, M., Rao, I.M., Lascano, C.E., Berry, W.L., Ito, O., 2009. Evidence for biological nitrification inhibition in Brachiaria pastures. Proc. Natl. Acad. Sci. U. S. A. 106, 17301-17307.

Subbarao, G.V., Nakahara, K., Ishikawa, T., Ono, H., Yoshida, M., Yoshihashi, T., Zhu, Y.Y., Zakir, H., Deshpande, S.P., Hash, C.T., Sahrawat, K.L., 2013. Biological nitrification inhibition (BNI) activity in sorghum and its characterization. Plant Soil 366, 243-259.

Subbarao, G.V., Rondon, M., Ito, O., Ishikawa, T., Rao, I.M., Nakahara, K., Lascano, C., Berry, W.L., 2007. Biological nitrification inhibition (BNI) - is it a widespread phenomenon? Plant Soil 294, 5-18.

Sun, L., Lu, Y.F., Yu, F.W., Kronzucker, H.J., Shi, W.M., 2016. Biological nitrification inhibition by rice root exudates and its relationship with nitrogen-use efficiency. New Phytol. 212, 646-656.

Suter, H., Sultana, H., Turner, D., Davies, R., Walker, C., Chen, D., 2013. Influence of urea fertilizer formulation, urease inhibitor and season on ammonia loss from ryegrass. Nutr. Cycl. Agroecosyst. 95, 175-185.

Sutton, M.A., Bleeker, A., Howard, C.M., Bekunda, M., Grizzetti, B., de Vries, W., van Grinsven, H.J.M., Abrol, Y.P., Adhya, T.K., Billen, G., Davidson, E.A., Datta, A., Diaz, R., Erisman, J.W., Liu, X.J., Oenema, O., Palm, C., Raghuram, N., Reis, S., Scholz, R.W., Sims, T., Westhoek, H., Zhang, F.S., 2013. Our Nutrient World: The Challenge to Produce More Food and Energy With Less Pollution. Centre for Ecology and Hydrology, Edinburgh.

Sutton, M.A., Skiba, U.M., van Grinsven, H.J.M., Oenema, O., Watson, C.J., Williams, J., Hellums, D.T., Maas, R., Gyldenkaerne, S., Pathak, H., Winiwarter, W., 2014. Green economy thinking and the control of nitrous oxide emissions. Environ. Dev. 9, 76-85.

Tanaka, J.P., Nardi, P., Wissuwa, M., 2010. Nitrification inhibition activity, a novel trait in root exudates of rice. AoB Plants 2010, plq014. http://dx.doi.org/10.1093/aobpla/ plq014. 
Terman, G.L., 1979. Volatilization losses of nitrogen as ammonia from surface-applied fertilizers, organic amendments, and crop residues. Adv. Agron. 31, 189-223.

Thorup-Kristensen, K., 1993. Root development of nitrogen catch crops and of a succeeding crop of broccoli. Acta Agric. Scand. B Soil Plant Sci. 43, 58-64.

Thorup-Kristensen, K., 2001. Differences in root growth of nitrogen catch crops important for their ability to reduce soil nitrate-N content, and how can this be measured? Plant Soil 230, 185-195.

Thorup-Kristensen, K., 2006. Effect of deep and shallow root systems on the dynamics of soil inorganic N during 3-year crop rotations. Plant Soil 288, 233-248.

Thorup-Kristensen, K., Dresboll, D.B., Kristensen, H.L., 2012. Crop yield, root growth and nutrient dynamics in a conventional and three organic cropping systems with different levels of external inputs and $\mathrm{N}$ re-cycling through fertility building crops. Eur. J. Agron. $37,66-82$.

Thorup-Kristensen, K., Nielsen, N.E., 1998. Modelling and measuring the effect of nitrogen catch crops on nitrogen supply for succeeding crops. Plant Soil 203, 79-89.

Trenkel, M.E., 2010. Slow- and Controlled-Release and Stabilized Fertilizers: An Option for Enhancing Nutrient Use Efficiency in Agriculture, second ed. IFA-Intl. Fertilizer Industry Association, Paris.

Verbon, E.H., Liberman, L.M., 2016. Beneficial microbes affect endogenous mechanisms controlling root development. Trends Plant Sci. 21, 218-229.

Villalba, H.A.G., Leite, J.M., Otto, R., Trivellin, P.C.O., 2014. Fertilizantes nitrogenados: novas tecnologias. Informações Agronômicas 148, 12-18. http://www.ipni.net/ publication/ia-brasil.nsf/issue/IA-BRASIL-2014-148.

Walker, T.S., Bais, H.P., Grotewold, E., Vivanco, J.M., 2003. Root exudation and rhizosphere biology. Plant Physiol. 132, 44-51.

Watson, C.J., Akhonzada, N.A., Hamilton, J.T.G., Matthews, D.I., 2008. Rate and mode of application of the urease inhibitor $\mathrm{N}$-(n-butyl) thiophosphorictriamide on ammonia volatilization from surface-applied urea. Soil Use Manag. 24, 246-253.

Wen, Z., Shen, J., Blackwell, M., Li, H., Zhao, B., Yuan, H., 2016. Combined applications of nitrogen and phosphorus fertilizers with manure increase maize yield and nutrient uptake via stimulating root growth in a long-term experiment. Pedosphere 26, 62-73.

Wetselaar, R., Norman, M.J.T., 1960. Recovery of available soil nitrogen by annual fodder crops at Katherine, Northern Territory. Aust. J. Agr. Res. 11, 693-704.

White, R., Kirkegaard, J., 2010. The distribution and abundance of wheat roots in a dense, structured subsoil-implications for water uptake. Plant Cell Environ. 33, 133-148.

Whitehead, D.C., Lockyer, D.R., Raistrick, N., 1988. The volatilization of ammonia from perennial ryegrass during decomposition, drying and induced senescence. Ann. Bot. 61, 567-571.

Whitmore, A.P., Schröder, J.J., 2007. Intercropping reduces nitrate leaching from under field crops without loss of yield: a modelling study. Eur. J. Agron. 27, 81-88.

York, L.M., Carminati, A., Mooney, S.J., Ritz, K., Bennett, M.J., 2016. The holistic rhizosphere: integrating zones, processes, and semantics in the soil influenced by roots. J. Exp. Bot. 67, 3629-3643.

Zhang, D., Zhang, C., Tang, X., Li, H., Zhang, F., Rengel, Z., Whalley, W.R., Davies, W.J., Shen, J., 2016. Increased soil phosphorus availability induced by faba bean root exudation stimulates root growth and phosphorus uptake in neighbouring maize. New Phytol. 209, 823-831.

Zhao, X., Christianson, L.E., Harmel, D., Pittelkow, C.M., 2016. Assessment of drainage nitrogen losses on a yield-scaled basis. Field Crop Res. 199, 156-166.

Zhou, M., Butterbach-Bahl, K., 2014. Assessment of nitrate leaching loss on a yield-scaled basis from maize and wheat cropping systems. Plant Soil 374, 977-991. 
Zhu, B., Gutknecht, J.L.M., Herman, D.J., Keck, D.C., Firestone, M.K., Cheng, W.X., 2014. Rhizosphere priming effects on soil carbon and nitrogen mineralization. Soil Biol. Biochem. 76, 183-192.

Zhu, S.S., Vivanco, J.M., Manter, D.K., 2016. Nitrogen fertilizer rate affects root exudation, the rhizosphere microbiome and nitrogen-use-efficiency of maize. Appl. Soil Ecol. 107, 324-333.

\section{FURTHER READING}

Cunha, J.F., Casarin, V., Prochnow, L.I., 2010. Balanço de nutrientes na agricultura brasileira. Informações Agronômicas 130, 1-11.

Silva, A.G., Crusciol, C.A.C., Soratto, R.P., Costa, C.H., Ferrari Neto, J., 2010. Produção de fitomassa e acúmulo de nutrientes por plantas de cobertura e cultivo da mamona em sucessão no sistema plantio direto. Ciênc. Rural 40, 2092-2098. 